\title{
CORPORATE READJUSTMENTS AND THE EXCESS PROFITS CREDIT
}

\author{
Alger B. Chapmant and Brady O. Bryson*
}

The readjustment of corporate structures abounds in excess profits tax consequences. The inheritance of an incorporated enterprise by a successor company, whether a new or pre-existing entity, and whether by merger or by sale of assets; the split-up of an enterprise into successor companies, or into a parent-subsidiary pattern; the amalgamation of separately incorporated businesses, or elements thereof having economic unity, via mergers, consolidations, and liquidations; and the readjustment of the capital structure exclusively within the existing corporation-these are transactions the excess profits tax implications of which have been given extensive legislative recognition. These implications will and, indeed, already have taken a ranking position in the tax world.

The problems are manifold, and they reach into virtually all phases of the excess profits tax. Among others, there are involved the availability of excess profits credits to the extent unused by one or more of the companies in other taxable years; the redistribution of equity invested capital among the several taxpayers as their number and relationships are disturbed; changes effected in the status of borrowed invested capital; the drawing together, without duplication, of the aggregate base period income experience reflected in the rearranged corporate family; the effect on aggregate excess profits net income as hitherto separate loss and profit operations are brought into balance; the effect of short taxable years as corporate existences are terminated; and the uncertain reach of the adjustment for inconsistency with positions previously taken by the predecessor companies.

In all these, the effect upon the excess profits credit, whether based on income or invested capital, is normally the dominant consideration. In addition, the task of analyzing the statute is most acute with respect to this phase of the problem. Accordingly, this article will attempt a discussion of the problem of the excess profits credit involved in such corporate readjustments; and will approach the problem through an analysis of the controlling legislation as to both types of credit, and the results achieved thereunder.

$\dagger$ A.B., 1926, Williams College; LL.B., I930, Columbia University. Member of the Now York and District of Columbia Bars. Office of Legislative Counsel, U. S. Senate, 1930-32. Lecturer and writer on tax matters.

*A.B., 1935, Western Maryland University; LL.B., I938, Columbia University. Member of the Philadelphia and District of Columbia Bars. Lecturer and contributor to legal periodicals. 


\section{The Invested Capital Credit}

The effect of a corporate readjustment on invested capital may vary widely in terms of dollars of credit, depending on a number of crucial factors. The more important of these factors frequently are whether or not there occurs a "reorganization," for income tax purposes, within the limited and in many respects artificial definition in Section Ir2(g) of the Internal Revenue Code; whether the readjustment is effected within an existing and single technical corporate entity, or involves a newly-organized corporate vehicle, or a combination of one or more existing structures; to what extent "identity" between the reorganized and unreorganized entities prevails; the equity-debt relationship of the capital structure, and other characteristics of the securities involved; and whether the transaction effects an intercorporate liquidation or its equivalent.

The importance of many of these, when brought to light in the following discussion, will be seen as the mere capricious effect of cross-play between various provisions of the income and excess profits tax and, in a broader sense, of a legislative failure to draw together a basic and consistent concept of investment for purposes of the excess profits tax.

Before attempting an analysis of the provisions of the Internal Revenue Code dealing specifically with problems of corporate readjustment, it will be well to summarize the basic statutory concept of "invested capital" applicable to taxpayers in general, as laid down in Sections 718 and 719 of the Code.

\section{General Rule of Sections 718 and 719}

The invested capital credit is based on the total of the average daily amounts of "borrowed invested capital" and "equity invested capital." For present purposes, the former amount may be described merely as $50 \%$ of outstanding written or formal debt, as more fully detailed in Section 7I9. Subparagraphs (I), (2), and (4) of Section $7 \mathrm{r} 8$ (a) contain the general rules as to equity invested capital in which we are most interested. They establish the following major elements of equity invested capital:

(I) "Money ... paid in for stock, or as paid-in surplus, or as a contribution to capital."

(2) Property similarly paid in-"included in an amount equal to its basis (unadjusted) for determining loss on sale or exchange." If the property has been disposed of, the basis is determined under the law applicable to the year of disposition, but without regard to the value of the property as of March 1 , I9x3. If the disposition was prior to March I, I9I3, the basis is taken at fair market value of the property when paid in, and if the unadjusted basis of the property is a substituted basis, such basis is to be adjusted, with respect to the period before the property was paid in, by an amount equal to the adjustments proper under Section II5(l) for determining earnings and profits. 
(3) The accumulated earnings and profits as of the beginning of the taxable year.

It will thus be seen that, so far as Section 7I8 is concerned, the basic pattern for statutory "invested capital" is capital originally paid in, whether in the form of money or other property, plus accumulated earnings; and that for this purpose, property is frequently taken at its cost, ${ }^{1}$ which will be either the property value when paid in or the value of the stock, if different. ${ }^{2}$

It will also be readily realized that (in addition to variable results depending upon whether the stock may be valued at other than the value of the property) a departure from value of the property when paid in will take place under Section 7r8 wherever for income tax purposes the basis of the property is determined by reference to the basis thereof in another's hands. The situations in which this may occur are so numerous as to raise a question as to which is the more general rule. They include, as to property still held, the following types of acquisitions:

(I) Transfers to a controlled corporation, within Sections $\operatorname{II2}(\mathrm{b})(5)$ and $\operatorname{II} 3(\mathrm{a})$ (8) (A), including "boot" transactions, after December 3I, I920. (Transfers before that date, although of a similar nature, will be controlled by the rule of cost.)

(2) Property acquired as paid-in surplus or as a contribution to capital, after December 3I, I920, within Section $\operatorname{Ir} 3(a)(8)(B)$. (Here property value controls if the acquisition is prior to that date.)

(3) Property paid in for stock after December 3r, I9I7 but prior to 1936 if-

(a) A $50 \%$ interest or control remained in the same persons, or any of them, within the meaning of Section $\mathrm{II}_{3}(\mathrm{a})(7)$; and the property was either

(b) acquired at any time during such period pursuant to a "reorganization" within the meaning of Section $\operatorname{II2}(\mathrm{g})$ of the Code; ${ }^{3}$ or

(c) acquired during I934 or I935 pursuant to a "reorganization" within the meaning of Section $\mathrm{II} 2(\mathrm{~g})$ of the Revenue Act of $\mathrm{x} 934^{4}$ or

(d) acquired prior to I934 pursuant to a "reorganization" within the meaning of Section II2(i) of the Revenue Act of 1932 (whether or not the I932 Act was then in force). 5

(4) Property paid in for stock during the taxable year 1936 , or a subsequent taxable year, if in connection with a "reorganization" within the meaning of Section II2(g) of the Code. ${ }^{6}$ (Here the percentage of retained interest is not material to the basis provision.)

(5) Property acquired by a railroad corporation after December 31, 1939, or by a street, suburban, or interurban electric railway corporation after December 3I, I934, pursuant to a court order as a result of an insolvency reorganization.?

\footnotetext{
${ }^{1}$ The unadjusted basis for determining loss is normally cost. See INT. Rev. Code \$ri3(a).

2 The cost of property paid in for stock is the value of the stock, which in turn is, for the lack of better evidence, frequently determined by reference to the value of the property. When a discrepancy can be shown, however, the stock value controls. See Pierce Oil Corporation, 32 B.T.A. 403, 430 (1935).

${ }^{8}$ INT. Rev. CODE §II3 (a)(7)(A).

'Id. $\S \mathrm{Ir}_{3}(\mathrm{a})(\mathrm{I} 6)$.

Id. $\$ \operatorname{riz}_{3}(\mathrm{a})(7)(\mathrm{B})$.

${ }^{5} 1 d$. $\$ \mathrm{II}_{3}(\mathrm{a})(\mathrm{I2})$.

${ }^{2} I d . \$ \operatorname{Ir}_{3}(\mathrm{o})(20),(2 \mathrm{I})$.
} 
The underlying details involved in determining to what extent a corporation's various and frequently numerous property acquisitions for stock, or as paid-in surplus or contributions to capital, fall within the foregoing assortment of categories is little short of amazing. Since the above material is set forth largely for purposes of background, such detailed problems cannot be here developed. ${ }^{8}$ It may also be noted, however, that further wide variation is encountered with respect to portions of the property originally paid in but disposed of prior to the taxable year, in that the law as to basis in effect in the year of disposition is followed, ${ }^{9}$ but without regard to March I, Igr3 value if such law makes reference to such value. ${ }^{10}$ Moreover if under the above rules a carry-over basis is appropriate for invested capital purposes, such basis must be reconstructed for the period held by the predecessor taxpayer (or taxpayers, if the immediate transferor acquired the property on a transaction resulting in a carry-over basis) by adjusting only on the basis of cost at the inception of the basis chain, in accordance with Section II5(1). Finally, if the disposition occurred prior to March I, I9I3, the flat rule of property value when paid in is followed.

There is little, if any, rational justification for a statutory definition of invested capital made up of such a hodge-podge of "values." An explanation of why such an incredible base for the measurement of excess profits could be adopted probably lies to some extent in an obviously mistaken notion of simplicity. The statutory rules do not, as is popularly supposed, avoid the necessity for valuing property. In all cases cost or value is the point of departure in determining basis. The use of carry-over basis as a measure simply forces the point of valuation back to a remote point in the chain of ownership, where values are likely to be more difficult to prove. A further answer is found in the adherence, through inertia, to finespun and unrealistic concepts developed, refined, and limited for a wholly different tax purpose-a temporal, not a qualitative issue-i.e., in which taxable year a realization of gain or loss should be recognized in computing income tax.

Whatever the merits of the foregoing rules, however, they are the point of departure from which the invested capital consequences of corporate readjustments are to be determined, as more specifically outlined in provisions designed exclusively for

\footnotetext{
${ }^{8}$ Consider, for example, the uncertain and overriding judicial principles involved in the tax concept of "reorganization" such as what is "continuity of interest," Helvering v. Minnesota Tea Co., 296 U. S. 378 (1935); LeTulle v. Scofield, 308 U. S. 415 (1940); Helvering v. Alabama Asphaltic Limestone Co., 315 U. S. 179 (1942); Helvering v. Southwest Consolidated Corp., 315 U. S. 194 (1942); or "germane to a business purpose," Gregory v. Helvering, 293 U. S. 465 (1935); or a "party to reorganization," Helvering v. Bashford, 302 U. S. 454 (1938); Groman v. Commissioner, 302 U. S. 82 (I937).

${ }^{0}$ Thus, for example, in 1928 an $80 \%$ retained interest or control was necessary for the carry-over of basis upon a "reorganization." Rev. Act of $1928, \$ \mathrm{rr}_{3}(\mathrm{a})(7)$. Generally speaking, prior to $19 \mathrm{I}_{7}$ there were no carry-over basis provisions, and prior to Igr3 $_{3}$ no tax provisions at all.

${ }^{10}$ Since 1934 the basis for determining loss has been cost. See INT. REv. CoDE, $\$ 1 I_{3}$ (a), (I4). Under the Rev. Acts of $x 924$ to I932, however, such basis was the greater of cost or March I, Igr3 value. See, e.g., Rev. Act of $\mathrm{r}_{932}, \$ \mathrm{II}_{3}(\mathrm{a})\left(\mathrm{r}_{4}\right)$. Prior to that period it was the lesser of the two, i.e., after the I9I6 Act. Compare the Igr 8 Act, $\$ 202(a)$ and Rev. Act of I921, $\$ 202(b)$.
} 
such readjustments. These special provisions may be divided into two broad cate. gories dealing respectively with "exchanges" and "intercorporate liquidations."

\section{Exchanges-Section 760}

Section 760 was added to the Code by Section 230(a) of the Revenue Act of I942, and is applicable only to taxable years beginning after December 31, 194x-in the absence of election by the taxpayer under Section 230 (d) of the Act to apply the new section in computing tax for all taxable years beginning after December $3 \mathrm{I}$, I939. As a part of the same legislative plan, Section 229(b) of the r942 Act makes pre-existing law on the subject of exchanges-Sections $75^{\circ}$ and $75^{\mathrm{I}}$-inapplicable to any taxable years beginning after December $3 \mathrm{I}$, I94I. ${ }^{12}$ The effect of the old and new provisions may conveniently be developed by comparison with each other.

The scope of Sections $75^{\circ}$ and $75^{\mathrm{I}}$ is limited to transactions qualifying as an "exchange," which is defined (somewhat less briefly) as a transaction to which Section $\mathrm{II2}(\mathrm{b})$ (4) or $\mathrm{II2}(\mathrm{b})$ (5) (or similar provisions of prior laws) were applicable, or a transaction by which property was acquired as paid-in surplus or a contribution to capital after December $3^{\mathrm{r}}$, I9I7. In contrast with this clumsy enumeration in Section 750 of eligible transactions, Section 760 has substituted a streamlined definition under which an "exchange" includes any transaction by which one corporation receives property from another corporation and the basis of the property received, for the purposes of Section $7 \pi 8(a)$, is determined by reference to the basis in the hands of the transferor.

These transactions have been previously described in the discussion of Section $7 \mathrm{r} 8(\mathrm{a})$. They include the acquisitions by means of a "reorganization," transfers to a "controlled corporation," and capital contributions covered by Section 750, and extend beyond it in at least two respects: First, the addition of Sections rr2(b) (9), II3(a) (20) and II3(a)(2I) by Section I42 of the I942 Act has resulted in a further type of transaction in which basis is carried over on a transfer of property between certain corporations, despite the fact that a new basis would have been determined under prior law. These provisions (previously mentioned) are confined, however, to the transfer of property in effecting the plan of reorganization of a railroad or electric railway company under bankruptcy and receivership laws pursuant to court direction. Second, Section $7 \mathrm{r} 8$ (a) (2), as amended by the 1942 Act, applies the law in effect in the year of disposition, in the event property has previously been disposed of, in determining whether a carry-over basis resulted at the time of acquisition. This rule is not in effect under Section $75^{\circ}$ with the result that, to use an example previously indicated, property acquired and disposed of prior to $193^{2}$ upon

\footnotetext{
${ }^{11}$ It should be here mentioned that throughout this article the writers have freely borrowed on several occasions from an earlier article, touching some phases of the subject, written by one of them. See Bryson, The Excess Profits Tax Provisions of the Revenue Act of 1942 (I943) 9I U. OP PA. L. REv. 394. Thanks are extended to the University of Pennsylvania Law Review for this privilege.

${ }^{12}$ It may be also noted that $\$ 229(\mathrm{a})$ of the Rev. Act of 1942 repealed $\$ 752$ (highest bracket amount) as of the date it was originally enacted.
} 
a "reorganization" in which $50 \%$ but less than $80 \%$ interest or control was undisturbed, would fall within Section 760 , but not Section 750 .

It should also be noted once more that Section 218 of the 1942 Act amended Section 7I8(a) (2) of the Code, to provide that where the basis of property to be included in invested capital is a substituted basis, the adjustments with respect to the period before the property was paid in shall be those computed under Section II5(1) applicable to the determination of earnings and profits. Section $760(a)(2)$ provides that basis, for the purposes of Section 760 , shall be determined in accordance with Section $7 \mathrm{I} 8$ (a). As a result, the new rule as to adjustments is a part of Section 760 , although not a part of Section $750^{13}$ This amendment corrects many situations where the adjustment to the basis for the period prior to the exchange, in the manner required by Section $\mathrm{II}_{3}(\mathrm{~b})(2)$, would produce an erroneous result. For example, the basis for inclusion of property in invested capital is ultimately founded on cost, but depreciation adjustments under Section $\mathrm{Ir}_{3}(\mathrm{~b})(2)$ would be computed on a higher March I, Igr3 value. The amendment contemplates that adjustment for depreciation in the prior period should be based on cost, which is the basis on which accumulated earnings and profits for excess profits tax purposes are computed.

It will thus be seen that property taken into equity invested capital at a carryover basis under Section 718 (a) also falls within Section 760 , if transferred by a corporation, and in either case would be taken in at the same basis figure. So far, this is mere duplication. What, then, is the effect of Section 760 ?

As a matter of mechanics, Section 760 merely provides that the amount taken into invested capital under Section 7r8(a), by reason of the acquisition of property on a carry-over basis from another corporation, shall be reduced by the sum of (I) any liabilities of the transferor assumed on the exchange, or any liabilities to which the property so received was subject; (2) any liabilities (typically bonds) of the transferee constituting consideration for the property received; and (3) any money or other property (at fair market value) paid to the transferor. In addition, if the sum of these amounts exceeds the basis of the transferred assets, the excess is thereafter treated as a reduction in daily invested capital.

So much for the mechanics of Section 760. Its effects and functions are less apparent than the steps involved in its literal application. One of the principal functions of the section is to provide a rule of allocation in a situation where, on an "exchange," property is paid in to some extent for stock (or as paid-in surplus or a contribution to capital) and also in consideration of liabilities assumed or secured by the transferred property, cash or other property. As will be seen from the formula prescribed by the section, the property paid in on the exchange is first applied to these forms of consideration paid by the transferee, and only the remainder is allocable to the stock.

\footnotetext{
${ }^{15}$ Query whether the new rule would apply to past years if the application of $\$ 760$ is elected, i.e., are the changes in $\$ 718$ (a) thus also given retroactive effect?
} 
A second effect, if not a function, of Section 760 relates to the excess profits treatment of earned surplus as opposed to capital or paid-in surplus. The formeraccumulated earnings and profits-is included in equity invested capital, as explained above. However, a deficit in earnings is not so included, in the sense that the full amount of capital and paid-in surplus is recognized without diminution on account of operating losses. This is the so-called "deficit rule." If, however, the losses serve only to reduce an accumulation of earnings, such losses are reflected in invested capital from year to year, since only the net balance of earnings as of the opening of the taxable year is counted.

Section 760 does violence to both of these rules. For example, if the transferor on an exchange has a deficit, and transfers all its assets to the transferee in exchange solely for stock of the latter, it will be seen that the invested capital so transferred will be less, in the amount of the deficit, than that previously avaliable to the transferor. This is because the addition to the invested capital of the transferee will not exceed the basis of the transferred assets; and a portion of the assets has been lostin the amount of the deficit-which was previously reflected in the invested capital of the transferor (or an equal amount of assets to which they have been converted). The vanished assets will not, of course, contribute to the invested capital of the transferee. ${ }^{14}$

On the other hand, if a surplus exists in the transferor, the transfer of all the assets on the exchange will not have the effect of "freezing" the surplus into "capital," for excess profits tax purposes, in the hands of the successor company-even though all the assets will now have been paid in for stock. Under the rule of Commissioner v. Sansome, ${ }^{14^{2}}$ the predecessor's earnings and profits become earnings and profits of the successor, and by adjustment under Section $7 \mathrm{r} 8(\mathrm{~b})(3)$ they are removed from the category of money or property paid in for stock. Therefore, they will continue to be eliminated from invested capital in the event of operating losses. In addition, such earnings and profits will be immediately eliminated, as a direct consequence of the reorganization, if the successor company has an earned deficit at the time of the reorganization in excess of such earnings.

A further function of Section 760 is to prevent, in a stringent manner, the reflection of unrealized asset appreciation in invested capital through the creation of funded debt against such value on an exchange; and in the absence of unrealized appreciation to work a conversion of equity invested capital to borrowed invested capital, and vice versa, where the debt ratio of the capital structure is shifted through the medium of a reorganization. Thus, if the predecessor company has an all equity structure, and a surplus, its invested capital will correspond, speaking roughly, to its net assets or the book value of its stock. If the net assets are transferred for a

\footnotetext{
14 The reduction in assets may take the form of adjustments for depletion, depreciation, and amortization, as well as complete losses.

14: 60 F. (2d) 93 I (C. C. A. 2d, I93I).
} 
combination of bonds and stock of the successor, such assets will first be attributed to the new bonds and only the remainder will be treated as equity capital. The bonds will be recognized as borrowed capital, and the section will, quite properly, thus have redistributed the invested capital in light of the new debt-equity ratio of the enterprise. ${ }^{15}$

Conversely, if assets were acquired by the predecessor by using its bonds (or their proceeds) as purchase money, and such assets (together with the other net assets of the corporation) are transferred to a new company solely for stock, such assets will be converted to equity capital.

The consequences are not so eminently rational where unrealized appreciation is involved, as may be seen from the following examples:

(r) The aggregate assets of the transferor have a value of $\$ 3,500,000$ and a basis in the transferor's hands of only $\$ \mathrm{r}, 000,000$; and for simplicity, no liabilities were outstanding. In the reorganization the taxpayer issued for the property its stock having a par value of $\$ I, 000,000$ and bonds in the face amount of $\$ 2,500,000$. The invested capital of the taxpayer would be a minus amount, the new company starting out "in the red," so to speak, although its predecessor had an invested capital of $\$ r, 000,000$ justifying a credit of $\$ 80,000$ ! The minus figure is computed as follows:

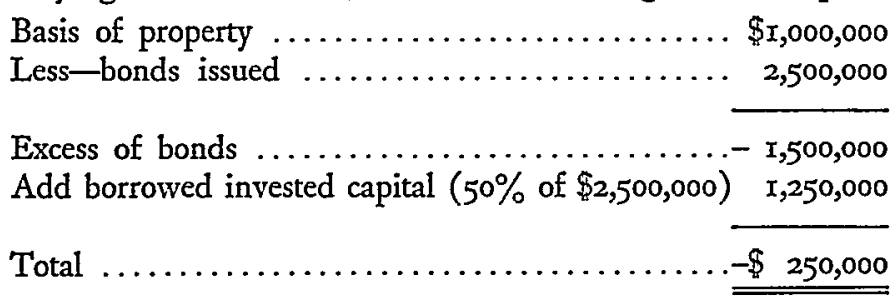

(2) If the added fact that there are $\$ 250,000$ of accumulated earnings and profits at the beginning of the taxable year is assumed, the invested capital would be exactly zero-despite outstanding debt of $\$ 2,500,000$; assets employed in the business having a value of $\$ 3,750,000$; and a tax basis, representing cash invested, of $\$ 1,250,000$ ! $^{16}$

(3) Assume, further, that accumulated earnings and profits at the beginning of the taxable year have increased to $\$ 2,500,000$ and that it has thus become possible to retire all the bonds. The invested capital, after the bond retirement would amount to $\$ 1,000,000$ computed as follows:

\begin{tabular}{|c|c|}
\hline $\begin{array}{l}\text { Basis of property } \\
\text { Less_-bonds issued }\end{array}$ & $\begin{array}{r}\$ 1,000,000 \\
2,500,000\end{array}$ \\
\hline $\begin{array}{l}\text { Excess of bonds issued ......... } \\
\text { Accumulated earnings and profits }\end{array}$ & $\begin{array}{l}-1,500,000 \\
. \quad 2,500,000\end{array}$ \\
\hline 1 & $\$ 1,000,000$ \\
\hline
\end{tabular}

${ }^{15}$ Section 751 , for some unknown reason, does not make this reallocation if the bonds are received free of tax on the exchange. In such case, they do not qualify as borrowed capital under \$75I, and do not operate to reduce equity capital.

${ }^{20}$ Under the formula of $\$ \$ 75^{\circ}$ and $75 \mathrm{I}$, invested capital would more sensibly be $\$ \pi, 250,000$. 
Note that the minus adjustment with respect to the bonds issued must still be taken into account even though such bonds have been redeemed. The earnings and profits from which the redemption was made remain in invested capital, and thus neutralize the continued minus adjustment, until wiped out by subsequent losses. When the earnings are thus impaired, the continuance of the minus adjustment becomes indefensible. For example, if $\$ 1,000,000$ in operating losses are then sustained, the invested capital would again be zero, although assets worth $\$ 2,500,000$ would make up the business.

In transactions where bonds were issued by the taxpayer as a part of the consideration for the property, the invested capital will probably be higher under the computation prescribed by Section 75I, because of the special treatment there afforded new bonds. This is especially true in cases where the bonds were called prior to I940. In such cases it probably would be more advantageous for the taxpayer to avoid electing the provisions of Section 760 in computing invested capital for 1940 and rg4r. Of course, for 1942 and subsequent years, there is no option.

As previously noted, it is the function of Section 760 to reduce invested capital by money or other property paid out by the taxpayer in acquiring property on an exchange. This is accomplished by reducing the property paid in on account of "boot," as indicated in the formula. This objective is proper, since such payments may be regarded as in the nature of distributions from capital or accumulated earnings and profits. A minus adjustment, with its distorted consequences, as in the case of new bonds, is incurred where the property received has appreciated, and such appreciation is in effect distributed by means of the exchange. A similar distortion may occur in case of appreciation in value of the assets paid out as boot. These assets are reflected in invested capital, either through capital or surplus, in the amount of their tax basis only; and the reduction in invested capital through the operation of Section 760 will be measured by their value. The dubious assumption that the assets coming in will add a tax basis figure equal to such value is indeed a finespun foundation on which to build a practicable statute. ${ }^{17}$

\section{"Identity" Reorganizations}

It has already been mentioned that one effect of Section 760 is to reduce invested capital in the amount of any deficit in earnings, if the business passes to a successor company on an "exchange." The Revenue Act of 1942 contains a provision, Section 2I9, designed to reverse this rule in the limited case where the successor company is in all practical aspects identical with its predecessor.

The objectives of the new provisions ${ }^{18}$ is to place the transferee corporation in the same position with respect to invested capital as the predecessor company prior to the reorganization, i.e., to leave equity invested capital unreduced by the occurrence

\footnotetext{
${ }^{17}$ This weakness may be offset somewhat by the increase in earnings and profits resulting from such disposition of the appreciated boot. This is of little comfort, however, to a corporation which has a deficit at the time of the exchange or thereafter.

${ }^{18}$ INT. REv. CODE $\$ \$ 718(a)(7),(5),(c)(5)$.
} 
of the deficit, but to require restoration of the deficit out of future earnings before including any plus amount of earnings and profits in invested capital. This is accomplished in part by adding to the invested capital of the transferee, as a separate item, an amount "equal to the portion of the deficit in earnings and profits of a transferor attributable to property received previously to such day," 19 thus restoring the deficit otherwise reflected through the operation of Section 760 of the Code. The deficit is maintained, for the purpose of computing earnings and profits as an element of invested capital, ${ }^{20}$ by treating the transferee as if it had been in existence immediately before the beginning of the taxable year in which the transfer occurred and had then sustained a recognized loss in such amount. ${ }^{21}$ The transferor on the other hand, receives the converse treatment. Its equity invested capital is reduced in the amount of the deficit; and its earnings and profits are computed for excess profits tax purposes as if a recognized gain had been realized immediately before the beginning of the taxable year of the exchange. ${ }^{22}$

The situation in which the new provisions may be applied is strictly limited by the following conditions: ${ }^{23}$

(I) "Substantially all" the property of the transferor corporation must be transferred to the transferee corporation. ${ }^{24}$

(2) The latter corporation must have been "formed to acquire such property."

(3) The "sole consideration" for the transfer of the property must be the transfer of all the stock (except qualifying shares) of the transferee to the transferor or its shareholder. However, the assumption of the transferor's liabilities, and liabilities to which the property is subject, are disregarded. ${ }^{25}$

${ }^{10} I d . \$ 718($ a) (7). Obviously, it will be impossible to attribute a deficit to particular property. This provision must mean that if less than all the assets are transferred, the deficit will be pro-rated in accordance with the proportion of the property transferred. It is so construed in U. S. Treas. Reg. 109, $\$ 718-7$, as amended by T.D. 5267 , May 27 , 1943.

${ }^{20}$ This will require a double computation of earnings and profits for tax purposes, as well as book surplus for corporate purposes.

${ }^{21}$ INT. REv. CODE $\$ 718(c)(5)$. This rule would seem to follow as a matter of course under the general theory of Commissioner v. Sansome, 6o F. (2d) 931 (C.C.A. 2d, 1931). It is possible, however, that the "Sansome rule" may not apply to deficits. Sec Rudick, "Dividends" under the Income Tax Law (194I) 89 U. of PA. L. REv. 865, 896. In any event, the statutory rule should be read as at most ratifying and not duplicating the "Sansome" adjustment.

${ }^{22}$ These adjustments will be of little consequence. The new provisions apply only to the determination of daily invested capital after the exchange. Since the transferor must be "forthwith completely liquidated" (condition (5) in the subsequent text), adjustments to the transferor's invested capital will be for a brief period only.

${ }^{23}$ INT. ReV. CODE \$718(c)(5).

${ }^{34} \mathrm{Cf}$. id. $\$ \mathrm{I} 12(\mathrm{~g})(\mathrm{I})(\mathrm{C})$. The phrase "substantially all," has not proved a very satisfactory legislative tool in the past. See Pillar Rock Packing Co. v. Comm'r, 90 F. (2d) 949 (C.C.A. 9th, 1937) (68\% insufficient); Comm'r v. First National Bank of Altoona, ro4 F. (2d) 865 (C.C.A. 3rd, r939) $(86 \%$ sufficient); Western Industries Co. v. Helvering, 82 F. (2d) 46I (App. D.C., 1936); Gross v. Comm'r, 88 F. (2d) 567 (C.C.A. 5th, 1937); Daily Telegram Co., 34 B.T.A. Ior (1936); American Foundation Co. v. U. S., I20 F. (2d) 807 (C.C.A. 9th, I94I) (value, not cost, is the measure); Schuh Trading Co. v. Comm'r, 95 F. (2d) 404 (C.C.A. 7th, I938) (worthless assets disregarded); Milton Smith, 34 B.T.A. 702 (1936) (assets withheld to pay debts disregarded).

${ }_{25} \mathrm{Cf}$. INT. REv. CODE $\$ \$ \mathrm{II}_{2}(\mathrm{~b})(5)$, (g)(I)(C); U. S. v. Hendler, 303 U. S. 564 (I938); Helvering v. Southwest Consolidated Corp., 315 U. S. 194 (I942). 
(4) The transferor's basis for the property must carry over to the transferee. ${ }^{20}$

(5) The transferor must be "forthwith completely liquidated" in pursuance of a plan under which the property is acquired; and

(6) "Immediately after the liquidation"27 the shareholders of the transferor must own all such stock.

The foregoing treatment of "identity" reorganizations does not approach an adequate treatment of the problem. For example, the new provisions completely fail, apparently, to cover the case of two or more transferors of assets to the new corporation, or the merger of existing corporations, even though proportionate interests are rigidly maintained.28 They cover only by implication the statutory merger of a predecessor and a new successor company-i.e., only if they recognize the constructive transfer of assets for stock, followed by a liquidating distribution and dissolution, in such a transaction. Moreover, the stringent limitations of the provisions will inevitably make their application very difficult. For example, the consideration must be limited "solely" to stock and assumed liabilities (or liabilities to which the property is subject), and this will exclude many reorganizations involving substantial identity merely because of new debt securities, stock warrants, liabilities assumed in the course of reorganization, and various other elements in the transaction which may in some way be classed as "consideration" other than stock and assumed liabilities. It will also unquestionably be necessary to cope with the question as to whether new debt securities issued in lieu of those outstanding at the time of reorganization represent an "assumption" of liabilities. ${ }^{20}$

\section{Intercorporate Liquidations}

Section 76 I of Supplement $C$ provides rules for the adjustment of invested capital at the time of tax-free intercorporate liquidations. It replaces Section $7 \mathrm{r} 8(\mathrm{a})(5)$ and (b) (4), which do not apply to taxable years beginning after December 3I, r94r. Here, also, the taxpayer may elect to apply Section $76 \mathrm{r}$ to all years beginning after December 3I, I939 in lieu of Section 7r8(a) (5) and (b) (4).

The latter sections contemplate application only to tax-free liquidations under Section $I I 2(b)(6)$ occurring since January $I$, I936. They provide an increase or

${ }^{20}$ INT. Rev. CODE $\$ I_{I 2}(g)(\mathrm{I})(\mathrm{C}), \mathrm{II}_{3}(\mathrm{a})(7)(B)$. This would seem to follow as a matter of course without such a provision. The function or purpose of the phrase "for the purposes of this subsection" in the new $\S_{718(c)(5)(B)}$ is not readily apparent.

${ }^{37}$ The phrase "immediately after" the transfer or exchange has also proved a serious legislative stumbling block in the past. See INT. Rev. Code $\$ \$ \mathrm{riz}_{2}(\mathrm{~b})(5),(\mathrm{g})(\mathrm{I})(\mathrm{D}), \operatorname{II}_{3}(\mathrm{a})(7)(\mathrm{A})$; Bassick v. Comm'r, 85 F. (2d) 8 (C.C.A. 2d, I936), cert. den. 299 U. S. 592 (1936); Hazcltine Corp. v. Comm'r, 89 F. (2d) 5r3 (C.C.A. 3d, r937); Comm'r v. Schumacker Wall Board Corp., 93 F. (2d) 79 (C.C.A. 9th, 1937); Case v. Comm'r, 103 F. (2d) 283 (C.C.A. 9th, 1939); Heberlein Patent Corp. v. U. S, ro5 F. (2d) 965 (C.C.A. 2d, 1939); Portland Oil Co. v. Comm'r, 109 F. (2d) 479 (C.C.A. Ist, I940), cert. den. 3 I0 U. S. 650 (I940); Briggs-Darby Construction Co. v. Comm'r, Ir9 F. (2d) 89 (C.C.A. 5th, I94x); Handbird Holding Corporation, 32 B.T.A. 238 (I935); Columbia Oil \& Gas Co., 4 I B.T.A. 38 (1940), aff'd, II 8 F. (2d) 459 (C.C.A. 5th, I94I); Wilgard Realty Co., 43 B.T.A. 557 (194I).

${ }^{23}$ See U. S. Treas. Reg. 109, $\$ 30.718-7$. (1942).

${ }^{20}$ Cf. Helvering v. Taylor, I28 F. (2d) 885 (C.C.A. 2d, 1942); Louis E. Stoddard, 47 B.T.A. 584 
decrease of invested capital in the amount of the "gain" or "loss" on the liquidation. The "gain" or "loss" is based on the formula prescribed by the two sections. A gain is the excess of the adjusted basis of property received in the liquidation over the sum of the adjusted basis of the stock, the aggregate of liabilities assumed by the parent (or to which the property was subject) and the amount of any consideration given by the parent in connection with the liquidation. Conversely, a loss is the amount by which the basis of stock, liabilities assumed and any other consideration given, exceeds the basis of property received. Such losses are to be taken into account only to the extent of the parent's earnings and profits at the beginning of the taxable year for which invested capital is computed.

Section $76 \mathrm{r}$ is more complicated. Under this provision an "intercorporate liquidation" contemplates not only the receipt by the taxpayer of property on a complete liquidation which is tax-free under Section Ir2(b)(6) of the Code, or a corresponding provision of prior law (as in the case of Section $7 \mathrm{I} 8(\mathrm{a})(5)$ and (b) (4)) but also the receipt of property on an intercorporate liquidation to which "a provision of law is applicable prescribing the non-recognition of gain or loss in whole or in part upon such receipt (including a provision of the regulations applicable to a consolidated income or excess profits tax return, but not including Section II2(b) (7), (9) or (10) or a corresponding provision of a prior revenue law)."30 The writers have found no significance in the quoted subsection beyond the intercorporate liquidation during a consolidated return period, ${ }^{31}$ since it is immediately followed by a limiting phrase-"but only if none of such property so received is a stock or a security in a corporation the stock or securities of which are specified in the law applicable to the receipt of such property as stock or securities permitted to be received (or which would be permitted to be received if they were the sole consideration) without the recognition of gain." The latter clause eliminates the application of the section to the constructive liquidation involved in a "reorganization" of the subsidiary under which the taxpayer, as the parent, exchanges its stock in the old subsidiary for stock in the successor or reorganized corporation-no real change having occurred in the parent's position.

The operative provisions of the section are a prime example of the complex technique in legislative draftsmanship of which we have seen so much in recent times. Two working concepts-the "plus adjustment" and the "minus adjustment" -are set up in Section $76 \mathrm{I}(\mathrm{b})(\mathrm{I})$ and (2) with a third provision, Section $76 \mathrm{I}(\mathrm{b})(3)$, supplying the "rules" for arriving at such concepts under their individual definitions. In brief, the "plus adjustment" is the excess of money and the adjusted basis of

\footnotetext{
${ }^{30}$ INr. REv. CodE $\$ 76 \mathrm{I}(\mathrm{a})$. Note that the section erroneously refers to a non-existent $\$$ II2(b)(I0) of the Code, which was never enacted either as a Code provision or as a counterpart under prior laws; and to $\delta_{112}(b)(7)$ of the Code, which has never existed as a Code provision, although it was part of the Rev. Act of 1938. However, $\$ 112(b)(9)$ is an accurate reference to a new provision on railroad reorganizations.

${ }^{31}$ Statutory mergers and consolidations, where the surviving corporation owned stock in the merged company, are separately covered in $\$ 76 \mathrm{r}(\mathrm{f})$, under which the property attributable to such stock is treated as having been liquidated on an intercorporate liquidation.
} 
property, net of liabilities assumed, liabilities to which the transferred property is subject, and "boot" received by the taxpayer on the intercorporate liquidation over the adjusted basis of the shares surrendered therefor. The converse is the "minus adjustment." These formulas correspond to the "gain" and "loss" on tax-free liquidations under Section $718(a)(5)$ and (b) (4).

With the concepts of a "plus adjustment" and a "minus adjustment" thus tentatively defined, Section $76 \mathrm{I}(\mathrm{c})$ lays down additional "rules" which represent merely a further development of the meaning of such concepts for purposes of the section. These "rules" fall into two parts: (a) the rule where the liquidated stock has a "cost basis"; 32 and (b) the rule where the liquidated stock has "other than a cost basis." 33

The rule as to stock having a cost basis in effect specifies an artificial basis to be attributed to the property transferred in liquidation of the shares held by the taxpayer, for purpose of computing the plus or minus adjustment. The substance of it is to give to the net assets, for such purpose, the basis (adjusted cost) of the surrendered stock. Where the stock has "other than a cost basis," the normal carryover basis of the assets is used in computing the plus or minus adjustment. ${ }^{34}$

After these definitions are thus finally completed, Section $76 \mathrm{r}(\mathrm{d})$ and (e) prescribe the operative rule of the new provision. The plus adjustment or minus adjustment is to be made to the earnings and profits account of the taxpayer in the case of stock having a cost basis; and to the equity invested capital, as an additional element thereof under Section 718 (a) or a reduction thereto under Section 718 (b), in the case of stock having a basis other than a cost basis. Further, the assets are thereafter to retain the basis used in computing the plus or minus adjustment for all invested capital purposes. ${ }^{35}$

The Commissioner, with the approval of the Secretary, is specifically authorized to issue regulations as to the various determinations under the new provision, and with respect to liquidations extending over a long period of time. ${ }^{36}$

As previously indicated, the adjustment provided by Section $76 \mathrm{r}$ makes a distinction between liquidations where the stock of the subsidiary was held on a cost basis and those where the basis was other than a cost basis. The adjustment is to be made with reference to each share held, so that one rule may apply to part of the stock, and the other rule may apply to the rest. In the case of stock held with a basis other than cost, the adjustment is substantially that prescribed by Section

${ }^{32}$ INT. Rev. CODE $\$ 76 \mathrm{r}$ (c) (r).

${ }^{83} I d . \$ 76 \mathrm{I}(\mathrm{c})(2)$.

"Ibid. Query whether stock the basis of which is determined by reference to the basis of stock previously held (which had a cost basis) is stock having "other than a cost basis." It should not be so treated, but $\S I_{3}(a)$ of the Code treats basis so determined as an exception to the rule that the basis of property is cost. See $\$ I_{I 3}(a),(a)(6)$. Note that the consolidated returns regulations more carefully refer to basis carried over from a predecessor. U. S. Treas. Reg. IIo, $\$ \$ 33.31$ (c)(2)(iv)(F), (G), and (v) (A), as amended by T.D. 5245, March 13, r943.

${ }_{35}$ This will require a separate computation of earnings and profits for excess profits tax purposes. Note that the assets retain such basis even though transferred to another corporation, if a carry-over basis normally results from the transfer. See $\$ 76 \mathrm{r}(\mathrm{e})$.

${ }^{38}$ INT. REv. CODE $\$ 76 \mathrm{I}(\mathrm{g})$. 
7I8(a) (5) and (b) (4)-the difference being that the adjustment under Section 7I8(b) (4) is limited to the amount of the taxpayer's earnings and profits, whereas this is not true under Section $76 r$. It is not clear from the legislative history of Section $76 \mathrm{I}$ that this difference represents an intentional and not an inadvertent change of policy.

The theory behind the adjustment in the case of stock having a substituted basis will readily be seen if it is assumed that stock of the subsidiary was acquired in exchange for all of the stock of the taxpayer upon the organization of the latter and the subsidiary was subsequently liquidated in a tax-free liquidation. The invested capital of the taxpayer would consist of the basis of the subsidiary's stock originally paid in, increased or decreased by the difference between such basis and the net basis of the subsidiary's properties received in liquidation. Thus, the invested capital of the taxpayer would equal the aggregate tax basis of the subsidiary's assets reduced by its liabilities (which were assumed by the taxpayer). If the subsidiary had a balance of accumulated earnings at the time of liquidation, in theory the taxpayer would have invested capital exactly equivalent to the invested capital of the subsidiary. In view of the subsidiary's stockholders' continuity of interest in the taxpayer, this result is proper.

Suppose, however, that the subsidiary had an operating deficit at the time of liquidation. As in the case of Section 760 , the invested capital surviving the Section 76I adjustment will be reduced in the amount of the deficit, since it turns on the basis of assets still held and therefore will reflect an elimination or reduction of assets through operating losses. While the provisions relating to deficits at the time of "identity reorganizations" seek, in a limited way, to counteract this effect under Section 760 , no counterpart exists with respect to the same problem under Section $76 r$.

In cases where the basis for the liquidated subsidiary's stock was a cost basis, Section $76 \mathrm{I}$ takes an entirely new approach. The effect of the adjustment is to treat the assets of the subsidiary attributable to such stock as if they had been purchased directly by the taxpayer at the time the taxpayer acquired control of the subsidiary. Moreover, whatever adjustment is necessary to achieve this result is made directly to earnings and profits as if realized by a sale. "Control" for this purpose is defined in Section $76 \mathrm{r}$ (c) (3) as $80 \%$ of the voting stock, if such ownership continues until the liquidation has been completed. The method of computing the adjustment is elaborate and may best be shown by an example:

Assume that corporation $A$, the taxpayer, purchased all the stock of corporation $B$ for $\$ \mathrm{r}, 400,000$. At the date of purchase $B$ had depreciable property with a tax basis of $\$ 800,000$ and no other property or liabilities. Thus, if the property is considered to have as its basis $A$ 's cost for the stock, the property will have a basis of $\$ 1,400,000$. Next assume that at the time $B$ was liquidated, the property was $50 \%$ depreciated and that $B$ had other assets of $\$ 600,000$ and no liabilities. The adjustment to be made on account of the liquidation of $B$ would be computed as follows: 
Depreciable property (basis under $\$ 76 \mathrm{r}(\mathrm{c}$ ) at acquisition of control) $\ldots \ldots \ldots \ldots \ldots \ldots \ldots \ldots \$ 1,400,000$

Depreciated $50 \% \ldots \ldots \ldots \ldots \ldots \ldots \ldots \ldots \ldots \ldots \ldots \ldots, 700,000$

Leaving adjusted basis $\ldots \ldots \ldots \ldots \ldots \ldots \ldots \ldots, 700,000$

Other assets $\ldots \ldots \ldots \ldots \ldots \ldots \ldots \ldots \ldots \ldots \ldots, 600,000$

Total assets received in liquidation ........... $\mathrm{x}, 300,000$

Basis for $B^{\prime} s$ stock .................... I,400,000

Minus adjustment to earnings and profits of $A \ldots \$ 100,000$

This result is quite different from that reached under the adjustment prescribed by Section $7 \mathrm{r} 8(\mathrm{a})(5)$ and (b) (4), which would be as follows:

Depreciable property ( $B$ 's income tax basis) .....\$800,000

Depreciation $50 \% \ldots \ldots \ldots \ldots \ldots \ldots \ldots \ldots \ldots, 400,000$

Leaving adjusted basis $\ldots \ldots \ldots \ldots \ldots \ldots \ldots \ldots, \quad \mathbf{4 0 0 , 0 0 0}^{\mathbf{4}}$

Other property $\ldots \ldots \ldots \ldots \ldots \ldots \ldots \ldots \ldots \ldots, 600,000$

Total assets received in liquidation $\ldots \ldots \ldots \ldots \ldots \times, 000,000$

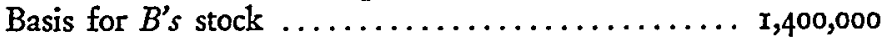

Reduction of invested capital under $\$ 718(b)(4) \ldots \$ 400,000$

The adjustment prescribed in this case under Section $76 \mathrm{I}$ is to be made to earnings and profits of the taxpayer, as if the taxpayer had realized a gain or loss equal to the plus or minus adjustment. In addition, the earnings and profits of the taxpayer, for the period following the liquidation, are to be computed by using this special basis for the assets received from the subsidiary-defined as "invested capital basis" by Section $76 \mathrm{r}(\mathrm{e})$. In the example given, $A$ would use the basis of $\$ 700,000$ for computing depreciation on the property acquired from $B$. This basis would be used to compute depreciation or gain or loss from sale to be taken into account in computing earnings and profits for invested capital purposes. In computing its taxable net income $A$ would use the adjusted income tax basis of $\$ 400,000$, which is a substituted basis carried over from the liquidated subsidiary. For example, if during the period from the date of liquidation to the beginning of the taxable year the property received from $B$ depreciated $10 \%$, a charge of $\$ 40,000$ would be reflected in $A$ 's income for income tax purposes. The adjustment required by Section $76 \mathrm{r}$, in addition to that for loss on liquidation, would be a further charge against accumulated earnings and profits of $\$ 30,000$ representing a difference between $10 \%$ of $\$ 700,000$ and $10 \%$ of $\$ 400,000$. As already mentioned, this reduction of earnings and profits by an adjustment of the charge for depreciation from $\$ 40,000$ to $\$ 70,000$ would be made only for the purpose of computing the earnings and profits to be included in invested capital. The invested capital basis for such assets would also be used, however, for the purpose of the inadmissible asset ratio computation. 
In the example the old rule and the new rule will tend to produce the same result by the time the property is fully depreciated, or in the event of sale. The difference would be more pronounced, however, if the excess of the cost of the stock over the tax basis of the subsidiary's assets represented a non-depreciable asset unlikely to be sold, such as good will. Under the old sections, the amount paid for such stock representing good will for which the subsidiary had no tax basis, becomes a reduction of the parent's invested capital at the time of the liquidation. Under the Section $76 \mathrm{r}$ adjustment, the amount of such good will would be taken into account as an asset at the amount paid for it by the parent through purchase of the subsidiary's stock. Thus, in such cases the taxpayer might increase the invested capital for 1940 and I94I by making the election to apply Section 76I rather than Section $7 \mathrm{r} 8(\mathrm{a})(5)$ and (b) (4).

Section $76 \mathrm{I}$ is replete with technical defects, and will either have to be rewritten, or perfected through a bold use of the power to make regulations. By way of supporting this general criticism, a few examples will be given, as follows:

(I) The simple situation in which a parent company purchases all of a subsidiary's stock for cash, and later contributes more capital to the subsidiary in exchange for additional stock, gives rise to a puzzling problem as to the manner of determining the assets attributable to shares of stock for purposes of an adjustment under Section $76 \mathrm{r}$ at the time of intercorporate liquidation. The proper result appears to be obtainable only by treating the amount paid in for the additional stock as a contribution to capital, increasing pro rata the basis of the shares previously held, rather than by attempting asset basis allocations on account of the stock subsequently acquired on the theory that such stock was independently purchased for cash.

(2) Section $76 \mathrm{r}$ refers merely to property received on liquidation attributable to a share of stock. No provision is made for the ordinary situation in which several classes of stock are held by the parent company and all are liquidated simultaneously. Some method of attributing the basis, in the case of shares purchased, of particular stock to the assets attributable to that stock, must be devised.

(3) Assume corporation $A$ purchased for $\$ 1,000,000$ in cash $80 \%$ of the stock of corporation $B$. Subsequently, corporation $A$ issued $\mathrm{x}, 000$ shares of its voting stock to corporation $B$ in exchange for $B^{\prime} s$ property. After this transaction $B$ was liquidated, and corporation $A$ received back (and cancelled) 800 shares of its own stock in the liquidation. ${ }^{37}$ The application of Supplement $\mathrm{C}$ would seem to permit $A$ to include as property paid in for stock, all of the assets of $B$ thus acquired. The transaction by which $A$ received its own stock in liquidation of $B$ would seem not to be included in the definition of intercorporate liquidation under Section $76 \mathrm{r}$. Accordingly, $A$ would seem to have a duplication in invested capital to the extent of

\footnotetext{
${ }^{37}$ This type of transaction is exemplified by Helvering v. Winston Bros. Co., 76 F. (2d) $3^{85}$ (C.C.A. 8th, 1935), and General Motors Corporation, 35 B.T.A. 523 (1937).
} 
the $\$ 1,000,000$ cash used to purchase stock of $B$ since this $\$ 1,000,000$ would represent either capital paid in to or accumulated earnings of $A$-unless the, surrender by $A$ of stock in $B$ for cancellation upon the liquidation of $B$ could be properly regarded as a distribution of a $\$ x, 000,000$ asset in retirement of its own shares.

(4) Assume that corporation $X$ purchased all the stock of $Y$ corporation for $\$ 2,000,000$ and that the assets of $Y$ had an aggregate basis of $\$ 500,000 . X$ transferred the stock of $Y$ to the taxpayer in exchange for all of the taxpayer's stock and $\$ \mathrm{I}, 000,000$ of bonds. Subsequently, the taxpayer acquired the assets of $Y$ by a taxfree liquidation. The invested capital of $Y$ would be zero, computed as follows:

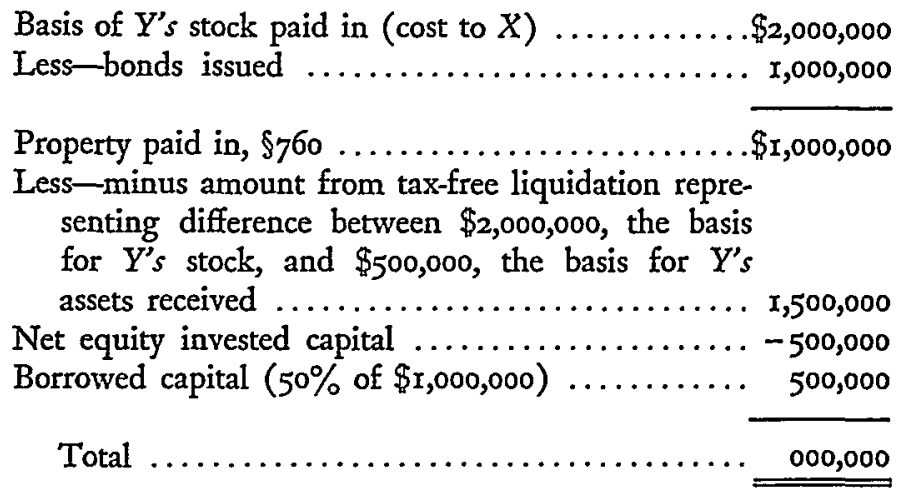

This result is obviously unsound since the taxpayer began operations with property having a tax basis of $\$ 500,000$ and with borrowed capital outstanding of $\$ r, 000,000$. Presumably the proper result would be obtained in a case such as this if the basis of the stock to be used in computing the plus or minus adjustment resulting from the liquidation, were the same basis determined under Section 760 as the amount includible in invested capital for the purposes of Section 718(a). Of course, if it were provided that the basis for Y's stock to the taxpayer is a cost basis, then the minus adjustment would not apply and the correct result would be produced.

(5) In some cases a parent corporation has purchased a substantial portion of the stock of the subsidiary but has not acquired until much later the $80 \%$ control referred to in Section $76 \mathrm{r}$. The adjustments prescribed in Section $76 \mathrm{r}$ adopt the date upon which $80 \%$ control is acquired as the time when the basis of the subsidiary's assets are to be adjusted with reference to the cost of its stock to the parent. Thus, for example, assume that $75 \%$ of the subsidiary's stock were purchased for an amount exactly equal to $75 \%$ of the aggregate tax basis of its assets and the subsidiary thereafter accumulated substantial earnings prior to the date on which additional stock was acquired, giving the parent $80 \%$ control. The assets of the subsidiary attributable to the $75 \%$ of the stock, would exceed the cost by $75 \%$ of the accumulated earnings. The adjustment prescribed would require that the subsidiary's assets attributable to $75 \%$ of the stock be scaled down to exclude the accumulated earnings attributable to such stock. There does not seem to be any reason behind this adjustment except 
that, to avoid being forced into an even more complicated set of rules which would produce the proper result in each individual case, the arbitrary date on which $80 \%$ control was acquired was probably selected.

(6) Section $76 \mathrm{r}(\mathrm{e})$ prescribes the so-called "invested capital basis" under which property received by the transferee in an intercorporate liquidation is thereafter for invested capital purposes regarded as having the same basis which was attributed to it under the plus and minus adjustment formula. Thus, in the case of the stock of a subsidiary having been acquired for cash, this provision requires that the cash purchase price of the stock ultimately become the tax basis of the subsidiary's assets. The application of this new basis to the assets is limited, however, to the case of property received "in an intercorporate liquidation." It commonly happens that assets are transferred from a subsidiary to a parent as a distribution from capital, with the intention that the subsidiary shall retain the remainder of the assets and continue operations. This distribution frequently would not qualify as an "intercorporate liquidation" even though the subsidiary was wholly owned. At a later point the subsidiary might be liquidated, and the assets then distributed would take the new basis for invested capital purposes, while those previously distributed would take a basis determined in light of the income tax law applicable to the prior distribution. This inconsistent and conglomerate result can be explained only as an oversight on the part of the draftsmen.

\section{The InCOMe CRedit}

\section{The Income Credit in General}

The income credit, popularly known as the "average earnings credit," rests upon the simple proposition that the normal portion of a corporation's current earnings can be determined by reference to its average earnings during a representative prewar period. The pre-war period I936 to I939 inclusive has been selected as a period of moderate prosperity for business in general. ${ }^{38}$

The embodiment of this basic proposition in the statute can be illustrated by applying the income credit to a corporate taxpayer which had reached its full normal growth by the beginning of the base period, which continued its customary business through the base period uninterrupted by any unusual or peculiar events, without any changes in its corporate set-up and as a member of an industry with a past record of consistent earnings and a normal business cycle.

For such a corporation reporting on a calendar year basis, the statute simply provides an excess profits credit of $95 \%$ of its average base period net income for the calendar years 1936 to I939 inclusive, plus $8 \%$ of its net capital addition and less $6 \%$ of its net capital reduction. ${ }^{39}$ The average base period net income for such a cor-

\footnotetext{
${ }^{33}$ See The Revenue Bill of 1942: H. R. Rep. No. 2333, 77th Cong., 2d Sess. (1942) 143; SEN. REP. No. 1631 , 77th Cong., 2nd Sess. (1942) I99. (Hereinafter cited as "House REPORT" and "Senate Report," respectively.)

${ }^{30}$ INT. REv. CODE $\$ 7 \times 3(a)$.
} 
poration is determined by making certain adjustments in its normal tax net income ${ }^{40}$ for each of the base period years comparable to the adjustments prescribed for converting the current normal tax net income into excess profits net income. ${ }^{41}$ Capital additions consist of increases in cash or property paid in for stock or as a contribution to capital, or as paid-in surplus, since the end of the base period, less increases in assets the income from which is not subject to the excess profits tax ${ }^{42}$ ("excluded capital"). Capital reductions consist of distributions out of capital to stockholders since the end of the base period. ${ }^{43}$ The net capital addition consists of the excess of additions over reductions. The net capital reduction consists of the excess of reductions over additions.

Aside from the minor adjustment from $100 \%$ to $95 \%$ of the average base period net income and, perhaps, the failure to recognize as a capital addition either accumulations of earnings since the end of the base period or $50 \%$ of borrowed capital acquired since the end of the base period, the statute produces a reasonably fair and simple measure of normal earnings for the corporate enterprise. Simplicity is converted into complexity, however, when an attempt is made to provide in the statute for the innumerable factors which tend to prevent the base period experience from being a fair measure of normal profits.

For example, the corporation may have been growing in the base period, without reaching its maturity until after the base period had ended. The larger profits in the current taxable year as compared to the average base period profits may represent merely mature profits rather than excess profits. The corporation may even have commenced business after the base period began and, therefore, is without any earnings at all for part of the period. Strikes, floods, fires, price wars or one or more of a host of other unusual or peculiar events may have occurred to interrupt or retard base period activity. Changes may have occurred in the character of the corporation's business the full effect of which may not have been reflected in the base period earnings. The base period may not constitute a representative period for the industry of which the corporation is a member. Finally, the present corporate enterprise may not even be the same enterprise that was operating throughout the base period by reason of mergers, consolidations, split-ups, liquidations and other rearrangements of corporate activity.

Any of the foregoing factors is capable of preventing the average base period earnings from being a proper standard of normal earnings in a particular case. Consequently, it has been found necessary to provide a number of variations in, and additions to, the basic statutory rule underlying the income credit in order to prevent discrimination and at the same time prevent windfalls. Most of the foregoing situations are taken care of, or are capable of being taken care of, by the application of Section $7 \mathrm{I}_{3}(\mathrm{~d})(2),{ }^{44}$ which fills up vacant periods during the base period with

\footnotetext{
${ }^{10} I d$. $\$ 7 \operatorname{Ir}(\mathrm{b})$.

${ }^{2}$ Id. $\$ 77_{3}(\mathrm{~g})(3)$.

4Id. \$7xI(a).

"And its counterpart in Supplement $A, \$ 74^{2}(e)$.

${ }^{43} 7 d . \$ 7 \times 3(g)(4)$.
} 
constructed earnings determined by reference to the corporation's invested capital at the beginning of the base period; by Section $7 \mathrm{r} 3(\mathrm{e})(\mathrm{I}),{ }^{45}$ the so-called automatic relief provision which permits the taxpayer to bring its leanest base period year up to $75 \%$ of the average for the other three base period years; by Section $7 \mathrm{r}_{3}(\mathrm{f})^{46}$ which prescribes the so-called normal growth formula in lieu of the four-year average rule; ${ }^{47}$ by Section 722 , the well-known general relief provision; and by Section $7 \mathrm{r}_{3}(\mathrm{~g})(5)$ and Supplement A which deal primarily with corporate rearrangements.

Thus, a simple rule of thumb has been developed largely by necessity into a maze of complicated phraseology with each clause and sentence presenting material for careful study. The discussion herein will be limited to a consideration of the provisions which deal primarily with corporate rearrangements, namely, Section $7 \mathrm{r} 3(\mathrm{~g})(5)$ and Supplement A.

\section{Section $7{ }^{1} 3(g)(5):$ Corporate Split-ups and Other Stock Relationships}

Section $7 \mathrm{I}_{3}(\mathrm{~g})$ (5) was introduced into the excess profits tax law by Section 216 of the Revenue Act of r942. ${ }^{48}$ It was immediately recognized as the Treasury's solution for a loophole in the statute which had remained open from the time it first appeared in the I940 Act. Prior to the introduction of this provision, a corporation, on the income credit basis and without any net capital addition could, in I940 or I94I, transfer a portion of its assets to a subsidiary and thereby create or increase an invested capital credit for the subsidiary without affecting its own income credit. True, if an existing subsidiary was used for such purposes, the step was taken with the expectation that the subsidiary would be forced to abandon its own highest bracket amount and share that belonging to the parent. ${ }^{49}$ This disadvantage, however, served only as a minor deterrent where sizable transfers were involved and now such disadvantage has been removed by the retroactive repeal of the highest bracket amount provisions. ${ }^{50}$

Generally speaking, the aim of the new provision is to establish a capital reduction (not merely an offset to the capital addition, if any) (1) $^{51}$ of corporation, based on increased holdings of affliates within the same "controlled group." However, the structure of the section is such as to raise considerable doubt as to how far and how well this aim will be achieved. The principal operative provisions of Section $7 \mathrm{r} 3(\mathrm{~g})(5)$ are as follows:

\footnotetext{
${ }^{45}$ And its counterpart in Supplement A, $\$ 742$ (b)(2).

10 And its counterpart in Supplement $A, \$ 742(h)$.

17 $\$ 7 \mathrm{r}_{3}(\mathrm{e})$.

48 The amendment is not retroactive. It applies only to taxable years beginning after December $3 \mathbf{I}$,

$\$ 0 \$ 752$ of the INT. Rev. CODE prior to I942 Act.

${ }^{60}$ Rev. Act of $1942, \$ 229$ (a)(I).

E1 To avoid a duplicate adjustment, it is provided that excluded capital shall be reduced by any increase in capital reduction as a result of the operation of the section.
} I94I. 
(5) If, on any day of the taxable year, the taxpayer and any one or more other corporations are members of the same controlled group, then the daily capital reduction of the taxpayer for such day shall be increased by whichever of the following amounts is the lesser:

(A) The aggregate of the adjusted basis (for determining loss upon sale or exchange) of stock in such other corporation (or if more than one, in such other corporations) acquired by the taxpayer after the beginning of the taxpayer's first taxable year under this subchapter, minus the aggregate of the adjusted basis (for determining loss upon sale or exchange) of stock in such other corporation (or if more than one, in such other corporations) disposed of by the taxpayer prior to such day and after the beginning of the taxpayer's first taxable year under this subchapter; or

(B) The excess of the aggregate of the adjusted basis (for determining loss upon sale or exchange) of stock in all domestic corporations and of obligations described in Section 22(b) (4), held by the taxpayer at the beginning of such day over the aggregate of the adjusted basis (for determining loss upon sale or exchange) of stock in all domestic corporations and of obligations described in Section $22(\mathrm{~b})(4)$, held by the taxpayer at the beginning of its first taxable year under this subchapter.

The definition of "controlled group" is virtually the same as that contained in the existing provisions with respect to "new capital."" A connecting link of more than $50 \%$ of total combined voting power, or of total value, is enough to bring a corporation within the chain of corporations constituting the controlled group.

When an attempt is made to ascertain the net effect of the new provision, it will be noted first that it is written in terms of affiliates' stock acquired or disposed of since the base period. It overlooks the ability of a parent to transfer assets, as a contribution to capital or paid-in surplus, to a subsidiary in existence before the end of the base period without acquiring any additional stock.

In addition, the objective of the section may in some cases be frustrated for other reasons. The net balance of acquisitions and dispositions under clause $(A)$ is measured in terms of the basis of the stock owned by the taxpayer; and shares held prior to the excess profits tax are included in the computation. ${ }^{53}$ Moreover, the reduction by reason of an increase in stockholdings within the "controlled group" is limited by the amount of the net increase, under clause (B), in excluded capital in general (stocks of all domestic corporations and tax-exempt securities). The result is that by disposing of high basis shares previously held (for example, a portfolio of depreciated and undesirable securities in affiliated companies held merely as investments) and transferring to a new subsidiary low basis assets in order to keep the basis on the acquired shares at a minimum, it might still be possible to eliminate or minimize the capital reduction while creating additional credit for the subsidiary. Or a corporation having a group of high basis "cats and dogs" qualifying as excluded capital and held prior to the imposition of the excess profits tax might clean

t2 INT. REv. CODE $\$ 718(a)(6)$.

${ }^{83}$ Shares disposed of prior to the day in question are included in the computations of shares held at the beginning of the first excess profits tax year at their basis under the law in effect at the time of disposition. 
them out, replace them with a new subsidiary's stock having an equal basis, and because of clause (B) again escape the capital reduction. Moreover, the additional specific exemption, and the excess of the credit based on the subsidiary's invested capital over the loss of credit by the parent, ${ }^{54}$ will also prevent full elimination of the tax advantage.

On the other hand, the provision will in some instances apply where the taxavoiding split-up is not present. Suppose corporation $A$ owns indirectly (through several intermediate corporations similarly connected) non-voting preferred stock of corporation $B$ exceeding in value $50 \%$ of the total value of $B^{\prime} s$ several classes of stock. $B$ has no capital addition. The management of $B$, which is by no means controlled by $A$, purchases some preferred stock of $A$ in the open market as an investment. Without more, $B$ suffers a reduction in its income credit. Yet even if $B$ had bought its own shares as an investment, apparently no capital reduction would have been suffered; ${ }^{55}$ and, of course, none would have occurred if the purchased stock had been that of a non-affliate.

\section{Supplement A: Merged and Reorganized Companies}

Supplement A of the excess profits tax, contained in Sections 740 to 744 of the Code, occupies the same position with respect to the income credit as Supplement $\mathrm{C}$ does with respect to invested capital. As Supplement C provides the method of aggregating the invested capital credits of consolidated enterprises, and passing invested capital from one company to another, so Supplement A seeks to coalesce the base period income experience of corporations absorbed into a single enterprise.

In actual operation it has no less a yield of knotty problems, requiring comparable finespun treatment. These problems grow out of many complicating factors such as the standards for eligibility; necessary adjustments for capital changes; "vacant" years, short years, or differing fiscal years in the base period; and the risk of duplication where the transferee of the assets (termed the "acquiring" corporation) and the transferor (termed the "component" corporation) both survive the transaction, or where there has been cross-ownership of stock between them.

Supplement A was extensively revised by the 1942 Act. With certain exceptions, hereinafter noted, the revisions may be applied retroactively to all excess profits. tax years at the election of the taxpayer. ${ }^{56}$ Such an election is normally advantageous when Supplement A is used. Accordingly, the discussion will refer to Supplement $A$ as amended.

\section{Eligibility for Supplement A: Types of Transactions Included}

By virtue of the 1942 Act, the right to use Supplement A has been extended to all corporations in existence before January I, I940, or having a component in ex-

\footnotetext{
${ }^{54}$ Due to a rate of return on invested capital (maximum $8 \%$ ) higher than the rate of adjustment for capital reduction $(6 \%)$.

${ }^{50}$ Cf. U. S. Treas. Reg. 109, \$30.718-5.

${ }^{\mathrm{E0}}$ Rev. Act of 1942, \$228(f); U. S. Treas. Reg. 103, \$30.742-2(e).
} 
istence before such date. Under prior law, a corporation only constructively in existence prior to January I, I940 (by reason of having a component actually in existence prior to such date) was compelled to use Supplement A, and one actually in existence prior to such date was put to an election between Supplement A and Section $73^{57}$ Now the taxpayer, in computing its average base period net income, is in effect entitled to the greatest of the regular or general average method; the growth provision; the Supplement A method; or the Supplement A-growth method. Moreover, only one set of computations need be submitted on the return, without disclaimer (as under prior law) ${ }^{58}$ of other methods, and the return is to be audited on the method so used. The taxpayer is not precluded, however, from shifting his method so long as the year remains open for adjustment. ${ }^{50}$

The 1942 Act made no change in the types of transactions covered by Supplement A. Section $740(\mathrm{a})$, which defines the term "acquiring corporation," limits the types of such transactions as follows:

(I) The acquisition by one corporation of substantially all the properties of another corporation where part or all of the consideration therefor is the transfer to such other corporation of all the stock of the acquiring corporation other than qualifying shares-Section $74^{\circ}(\mathrm{a})(\mathrm{I})(\mathrm{A})$.

(2) The acquisition by one corporation of substantially all the properties of another corporation where the sole consideration therefor is voting stock of the acquiring corporation-Section 740 (a) (r) (B).

(3) The acquisition by one corporation, prior to October I, I940, of properties of another corporation solely as paid-in surplus or as a contribution to capital, in respect of voting stock of the acquiring corporation owned by such other corporation -Section $740(\mathrm{a})(\mathrm{r})(\mathrm{C})$.

(4) The acquisition by a corporation of substantially all the properties of a partnership or sole proprietorship in an exchange which is or was covered by Section $\operatorname{II2}(b)(5)$, or so much of Section $\operatorname{II2}(c)$ or (e) as refers to Section $\operatorname{II2}(b)(5)$, or by a corresponding provision of prior law-Section $740(\mathrm{a})(\mathrm{I})(\mathrm{D})$ and $(\mathrm{h})$.

(5) A tax-free liquidation under Section $\operatorname{Ir}(b)(6)$ of the Code or a corresponding provision of prior law-Section 740 (a) (2).

(6) A statutory merger or consolidation-Section 740 (a) (3), (4).

With respect to (2) and (3) above, it is necessary that the corporation transferring its properties shall be completely liquidated forthwith in pursuance of the plan under which the transfer is made, and the transaction must have "the effect of a statutory merger or consolidation"-Section $740(\mathrm{a})(\mathrm{x})$. In determining whether the property was acquired in such exchanges solely for voting stock, as paid-in surplus, or as a contribution to capital, the assumption of liabilities is disregarded.

${ }^{5 x}$ Compare the first paragraph of old $\$ 742$ with the section as revised by $\$ 228(c)$ of the Rev. Act of 1942 .

${ }^{68}$ Old $\$ 74 \mathrm{I}(\mathrm{b})$ is repealed. See Rev. Act of $1942, \$ 224$ (b).

${ }^{50}$ See Rev. Act of r942: House Report, 153-r54; SENAte Report, 218. 
All the above transactions are, as a matter of form, of the kind with respect to which, under the law in effect since the beginning of the base period, gain or loss is not recognized and where the basis of the property in the hands of the transferor carries over to the transferee. ${ }^{60}$ In some cases this result follows from the fact that the transaction fits the definition of the term "reorganization" in Section $\operatorname{II2}(\mathrm{g})$ (I). The question naturally arises in such cases, therefore, as to whether eligibility for Supplement A treatment depends on meeting the additional tests that have been superimposed on the statute by judicial doctrine in the "reorganization" field. These include principally the "business purpose" and "continuity of interest" requirements and the "party to a reorganization" doctrine, which have been mentioned above in the discussion of the invested capital provisions. ${ }^{61}$

Although the matter is not entirely clear, it seems probable that such reorganization tests will be read into Supplement $A$ by the courts. The regulations flatly so state, ${ }^{62}$ and they would appear to be supported by enough of the rather inconclusive evidence of Congressional purpose to withstand attack. ${ }^{63}$

If it is true, however, that Congress intended to require Supplement A transactions to fit the mold of a tax-free reorganization, there nevertheless remains the question whether such a requirement reflects sound policy in light of the basic purpose which Supplement A should serve. The fundamental purpose of Supplement A would patently appear to be to permit the use of base period experience in cases where the assets contributing to such base period income find a new owner. There would appear to be no reason why this principle should not be extended to all cases where such assets are transferred to new ownership, provided (I) the danger of duplication in the use of base period experience is eliminated, and (2) the assets are dealt with as going business units, so as to avoid the difficulty of deciding how to allocate the base period earnings experience.

Possibly this latter qualification justifies for the most part the present limitations

${ }^{00}$ As to contributions to capital, type (3) above, see $\$ I_{13}(a)(8)(B)$. Types (4) and (5) are ex-

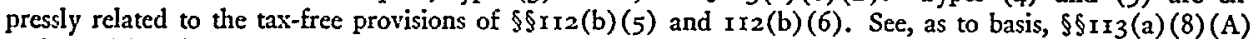
and $I_{3}(a)(15)$. Types (I), (2) and (6) above are not expressly tied in with the tax-free provisions of $\S I_{12}$, but, as a matter of form, they qualify under the definition of a "reorganization" in $\$ 1 \mathrm{r} 2(\mathrm{~g})(\mathrm{x})$. See $\$ \operatorname{Ir2}(g)(I)$, subsections (D), (C), and (A) respectively. See, as to basis, $\$ \S I_{3}(a)(6)$ and (7).

${ }^{\circ 1}$ See note 8 , stupra.

${ }^{03}$ U. S. Treas. Reg. 109, $\$ 30.740-2$ (b).

${ }^{83}$ The statute itself offers only slight evidence tending both ways. In opposition to the regulations it might be noted that the general heading of the supplements to the excess profits tax law is "Rules in Connection with Certain Exchanges"; and the word "reorganization" is not used in Supplement A. Moreover, from the fact that a tax-free result is expressly required in connection with liquidation transactions mentioned in $\$ 740(a)(2)$, it might be argued, on the expressio unius theory, that a taxfree result is not necessary with respect to $\$ \$ 740(\mathrm{a})(\mathrm{x})(\mathrm{A})$ and $(B)$ (types (I) and (2) above). On the other hand, several cross references in $\$ \$ 7 I 1,712$ and 713 mention Supplement $A$ as providing the rule in the case of "certain reorganizations." \$7II(b)(I), \$7I2(a) and (d), \$713(d)(4). And in addition, there are some general references in the committee reports to the transactions here in question as "tax-free exchanges" or as the types covered by $\$ \mathrm{II2}(\mathrm{g})(\mathrm{I})(\mathrm{C})$ or (D). Second Revenue Act of 1940: H. R. Rep. No. 2894, 76th Cong., 3d Sess. (x940) 30; SEN. Rep. No. 2rr 4, 76th Cong., 3d Sess. (1940) I8; id., Pt. 2, p. I6; Conference Report, H. R. Rep. No. 3002, 76th Cong., 3d Sess. (1940) 56. Excess-Profits Tax Amendments of r94I: H. R. Rep. No. 146, 77th Cong., Ist Sess. (I94I) I4; SEN. REP. No. 75, 77th Cong., Ist Sess. (I94I) I5. 
contained in Section 740 (a). However, these limitations can safely be extended, and statutory amendments to that end are desirable. It is not difficult to think of other cases where Supplement A treatment is fully as justified as in the cases now within the provisions of Section $740(\mathrm{a})$. One example would be a case where particular departments of one or more corporations are split off and put into a new corporation. Another would be the case where assets are acquired for preferred stock or even long-term bonds. To cite one more example, there is no reason why a corporation acquiring the assets of a partnership should not be permitted to avail itself of the base period experience of a sole proprietorship which preceded the partnership. ${ }^{64}$ Even if the present limits on the formal aspects of transactions eligible for Supplement A are to be retained, however, it is hard to find any reasonable justification for requiring that the exchange be tax-free in nature.

\section{The General Operation of the Supplement}

Once it is determined that assets have been acquired in a Supplement $A$ transaction during or after the base period the goal of the statute is to combine or coalesce the earnings experience of the "acquiring" and "component" corporations for each of the base period years; and to treat the combined annual base period earnings in substantially the same manner as the earnings of a single corporation under Section 713. The general operative provisions of Supplement A, contained in Section 742, provide for computation of the average base period net income substantially as follows:

(I) By aggregating for each base period year the net income or deficit ${ }^{65}$ of the taxpayer and of each component corporation for their respective taxable years beginning with or within such base period year. Under the 1942 Act the term "base period year" was permanently anchored to the four calendar years 1936-1939, and cannot, therefore, shift with changes in the taxable year of the acquiring corporation as under prior law. ${ }^{\text {B }}$

(2) By applying the $75 \%$ rule of Section $742(\mathrm{~b})$. This rule, which is designed to bring automatic relief to corporations having an unusually poor year (usually 1938 ) within the base period, brings the lowest base period year up to an amount equal to $75 \%$ of the average of the other three years. The rule is not peculiar to Supplement A. It was also brought into Section $7 \mathrm{r}_{3}$ (e) by the 1942 Act to replace a much less generous provision, applicable to prior years, ${ }^{67}$ which merely treated the deficit

\footnotetext{
[4 In the cases mentioned, however, the possibility of relief under $\$ 722$ should not be overlooked.

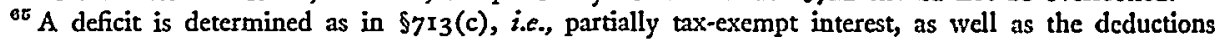
and dividends received credit, is deducted from gross income.

The change is not retroactive unless the taxpayer so elects; and the amendment is not available to a taxpayer which became an acquiring corporation prior to September I, I940, the base period for the first taxable year ending in I941 being applicable. Rev. Act of 1942, \$228(a); INT. REv. Code $\$ 740$ (d). See House Report, 152-153; Senate Report, 217; Conference Report, H. R. Rep. No. 2586, 77th Cong., $2 \mathrm{~d}$ Sess. 66.

${ }^{67}$ The Supplement A $75 \%$ rule applies only to taxable years beginning after Dec, 31, I941. It is not subject to the general privilege of elective retroactivity.
} 
year (the greatest if more than one) as $a^{-y e a r}$ in which no profit or loss was sustained.

(3) By taking the aggregate net result for the four years and dividing by four.

(4) As an alternative to the latter two steps, Supplement A taxpayers may now use the "normal growth" formula. Prior to the 1942 Act, this privilege was limited to ordinary income credit taxpayers using Section $7 \mathrm{r}_{3}$. The growth formula, contained in Section $742(\mathrm{~h})$, is intended to reflect the (assumed) continuation of an upward trend shown by an enterprise during the base period, and operates in the same manner as the provision for ordinary income credit taxpayers in Section $7{ }^{\prime} 3(f)$.

Certain minimum limitations on the average otherwise determined under the Supplement are set by Section 742 (d). This section states that the average base period net income shall in no case be less than zero. It further provides that in certain limited situations $^{68}$ the average base period net income of the taxpayer shall not be less than that of its qualified component having the greatest average base period net income, or that of the taxpayer computed without regard to that of any of the qualified components involved in the transaction.

Once the average base period net income has been computed under Supplement $A$ it is converted into an excess profits credit, as in the ordinary case under Section $7 \times 3{ }^{60}$ by taking $95 \%$ of such amount, and then adding $8 \%$ of the net capital addition or subtracting $6 \%$ of the net capital reduction. In making the latter adjustments for net capital changes in the taxpayer, Section 743 provides for transferring to the taxpayer the net capital addition or reduction of any component corporation. The provision, of course, affects only cases where components have been acquired since the base period. ${ }^{70}$ The section contains appropriate provisions requiring adjustment where the net capital changes of the taxpayer or a component are attributable to intercompany transactions. ${ }^{71}$ In addition, the ordinary operation of Section 743 is subject to modification in any case calling for the application of the anti-duplication provisions of Sections 740 (c) and $742(f)(r)$, hereinafter discussed.

Despite the 1942 amendments, one major defect remains in the provisions respecting net capital changes. Suppose the taxpayer corporation acquires after the base period, in exchange for its voting stock, the assets of a component corporation which was organized after the base period and therefore has no base period experi-

C8 This provision is limited to Supplement A transactions after Dec. 3I, 1939. It also requires that on Sept. II, I940 and at all times until the transaction, either the taxpayer or one of the qualified components involved must have owned at least $75 \%$ of the stock of the other corporations involved. The term "qualified component corporation" is defined as one in existence at the beginning of the taxpayer's base period. This relatively minor provision of the statute is the only one wherein the concept of the qualified component corporation has survived the 1942 amendments. See infra, p. 89

${ }^{00}$ As a matter of mechanics the credit is in all cases computed under $\$ 713$. See $\$ \$ 742$ (first sentence), $7_{3}(\mathrm{a})$, and $\mathrm{j}_{43}(\mathrm{a})$.

${ }^{70}$ Net capital additions and reductions are defined in terms of changes since the base period. $\$ 7{ }_{3}(\mathrm{~g})$.

${ }^{71}$ The details of these provisions were for the most part added by the Rev. Act of I942, $\$ 228$ (d). The committee reports state that the amendments were "clarifying" in nature. House REPORT, I55-6; Senate Report, 221. 
ence. $^{72}$ The component will contribute nothing to the taxpayer's income credit under Supplement A. Yet if Supplement A is used, the taxpayer will not be entitled to a capital addition on account of the acquisition of the assets of the component, and instead it will be given the capital addition (including the capital paid in upon the organization of the component subsequent to the base period) of the component-which may vary widely from the assets held by the component at the time of absorption. ${ }^{73}$ The purpose of the provision is only to prevent a double use of income from the component's assets, first through the Supplement $A$ average base period income and then through a capital addition on the acquisition of the component's assets. In the example given, no such duplication can occur, and if the section is applied as indicated, a distortion is inevitable.

\section{Special Problems in Computing Base Period Net Income: Fiscal Years, Short Years, Vacant Years, and General Relief}

The foregoing discussion of the procedure for computing average base period net income under Supplement A has, by and large, assumed that each corporation involved has a readily determinable earnings experience for each of the base period years, at least until the time of the Supplement $A$ transaction. This assumption avoids several complex problems. One difficulty under prior law has been mentioned -the possible shifting of the base period years, which has been avoided by the $194^{2}$ amendments. $^{74}$

In addition, the $194^{2}$ Act made several other corrections with respect to the base period income taken into account. Under prior law, the income of an acquiring corporation, and its components, included in Supplement $A$ average base period net income was limited to that earned in their respective taxable years beginning after December 3I, I935, and ending with or within the acquiring corporation's base period years; and the income of a component prior to the beginning of the taxpayer's base period was also excluded. This rule was unsound in various situations. For example, if the taxpayer's base period was the period of four calendar years I936-r939, the old rule excluded in the case of components using a fiscal year in the base period, both the income earned in 1936 until the close of the fiscal year beginning in 1935 , and that earned in 1939 after the close of the fiscal year beginning in I938. Only three years were thus reflected in the average. ${ }^{75}$ The new rule includes for each base period year all taxable years of the taxpayer and its components beginning with or within such base period year. This provision may work to the tax-

\footnotetext{
${ }^{32}$ Or which has lost its base period experience to another corporation of which it has previously become a surviving component. $\$ 740(\mathrm{c})$, hereinafter discussed.

${ }^{3}$ Thus assets acquired by the component for bonds, and then acquired in turn by the taxpayer for its stock when it absorbed the component, would not be reflected.

"See note 66, supra.

${ }^{75}$ For an excellent discussion and analysis of the incongruities resulting from the defective provisions of the original law, discussed herein, see Alvord, A Preliminary Analysis of the Excess Propits TAx of 1940 (1940) 66-69.
} 
payer's advantage where a fiscal year began late in I939 in that a business uplift in I940 may be partially reflected in the income credit.

Despite the above changes in the statute, questions arise where the taxpayer or a component has a short year, and possibly two taxable years, beginning in the same base period year. The problems are complex and have been largely left to be dealt with by the regulations. ${ }^{76}$ In general, the regulations prescribe the use of daily averages prorated for a twelve months' period, except where it can be clearly shown that actual experience over such a period yields a fairer result. However, the regulations, like the statutory provisions for normal growth in Sections $\eta_{3}(f)(7)$ and $742(\mathrm{~h})(2)$, permit no use of experience after May 3I, I940.

Other difficult problems are presented where the taxpayer or a component or both were not in existence during one or more base period years. Under the original law, the "vacant year" problem was largely by-passed by reason of the arbitrary limitations on the inclusion of base period experience. These limitations contained in the law prior to the I942 Act, required the following results: (I) only the base period experience of "qualified" components, that is those in existence at the beginning of the base period, could be taken into account; ${ }^{77}$ (2) even the experience of a component which was qualified only by reason of having itself acquired a component which was actually in existence at such time was includible only for the period subsequent to the acquisition of such component; ${ }^{78}$ and (3) the income of an acquiring corporation for the period prior to its becoming an acquiring corporation (if it was not actually in existence at the beginning of the base period) was likewise excluded. ${ }^{79}$ These were errors of draftsmanship in the Second Revenue Act of I940, resulting from the failure to keep the Supplement in harmony with the rest of the bill as its basic policy was changed in the course of its passage..$^{80}$

The 1942 Act, as stated above, corrects these errors to the extent of allowing the inclusion of all excess profits net income of both the acquiring corporation and its components for their respective taxable years beginning in the base period. Moreover, for those base period years in which neither the acquiring nor any component corporation was in existence, a constructed income based on $8 \%$ of invested capital of each corporation as of the beginning of its first taxable year beginning in I940, is allowed. ${ }^{81}$ Adjustments are prescribed, pursuant to regulations, to prevent the

${ }^{70}$ INT. REV. CODE $\$ 742($ a), last paragraph; U. S. Treas. Reg. 109, $\$ 30.742-2$ (b) (3)(ii) (A).

${ }^{77} \$ 742(a)(2)$ of prior law. A component not actually in existence on such date, but which had absorbed a component having such existence, was also "qualified." See old $\$ 740(f)$.

${ }^{78}$ See old $\$ 742(f)(2)$.

${ }^{78}$ See old $\$ 742(\mathrm{f})(\mathrm{r})$.

${ }^{80}$ The House version of that bill had required actual existence at the beginning of the base period as a prerequisite to any corporation's use of the income credit; and the Senate changed this requirement merely to existence prior to January $x, 1940$, allowing a constructed income for the vacant period. The Senate prevailed. See H. R. Rep. No. 3002, 76th Cong., 3d Sess. (1940) 47; INT. Rev. Cone \$712(a). But Supplement A was not revised to bring its limitations in line with this change in policy.

${ }^{81}$ Rev. Act of 1942, $\$ 228(\mathrm{c})$; INr. REv. CODE $\$ 742$ (e). This constructive income is available only if none of the corporations was actually in existence on Dec. $3 x$, 1936 . Corporations absorbed as components prior to the beginning of their acquiring corporation's first taxable year in r940 are not included in the adjustment directly, since their assets will be included through the acquiring corporation. 
doubling up of invested capital for purposes of computing the constructed income; on account of the cross ownership of stock between the corporations involved. ${ }^{82}$

This "fill-in" of vacant periods is unduly limited, if consistency with the constructive income afforded by the general provisions for the income credit is desired. The Act does not allow a fill-in under Supplement $A$ of a vacant period of any of the corporations in any base period year in which any one of the taxpayer and its component corporations was in existence. This appears to be an arbitrary rule. Obviously, the fill-in, as in the case of the non-Supplement A taxpayer, should be for the entire vacant periods of all corporations absorbed into the system. ${ }^{83}$

Still another problem in computing base period income to which the I942 Act supplied at least a partial answer is that of the relationship between Supplement $A$ and the general relief provisions of Section 722. Prior law did not cover the point, but the $1942 \mathrm{Act}^{84}$ added a provision to Section 722 which states that-

(e) Rules for Application of Section.-For the purposes of this section. . . .

(2) in the case of a taxpayer, the average base period net income of which is computed under Supplement A, for the period for which the income of any other person is included in the computation of the average base period net income of the taxpayer, the taxpayer shall be treated as if such other person's business were a part of the business of the taxpayer.

A ruling issued by the Commissioner in explanation of this provision acknowledges that Supplement $A$ and Section 722 relief are not mutually exclusive. ${ }^{85}$ It seems clear that Supplement A may be used in conjunction with reconstructed base period income for an acquiring corporation or any one or more of its components or both. However, the approach of the Commissioner will be to look at the enterprise as a whole in determining the amount of relief which will be granted; and the

In constructing the income, an inadmissible asset adjustment based on the last year beginning in 1939 is made, including the assets taken over from any component during the year, as well as those remaining from previous acquisitions of components. Where an acquiring corporation absorbs a component after such day but within the component's last taxable year beginning in the base period (i.e., in r939), the component's income in the vacant period is similarly constructed as of the day it was taken over.

$82 \$ 742$ (e)(3); U. S. Treas. Reg. I09, $\$ 30.742-2$ (d). For an example of the operation of this provision, see Rev. Act of 1942 , Conference RePort, 66-67. Note that the examples given in the House Report (pp. 154-155) and the Senate Report (p. 220) are covered by the new $\$ 742$ (f) (r), discussed below.

${ }^{83}$ It may have been thought that the absorption of an additional corporation into the system after the basic corporation had been organized, is analogous to a capital addition during the base period, and consistently with the rule with respect to capital additions, the income prior to the absorption or addition should not be built up. The difficulty with this reasoning is that the rule with respect to capital additions is also unsound, in light of the purpose to reflect in the credit the normal profits of the business as it existed at the beginning of the excess profits tax, with adjustments for capital changes thereafter. Note, however, that the provision for putting a short year on an annual basis will fill in some vacant periods. See p. 89 , supra.

$84 \$ 222(a)$. This amendment like all amendments to $\$ 722$, is applicable to all taxable ycars beginning after Dec. 3I, 1939. \$222(e)(I).

${ }^{85}$ I.T. 36I7; I.R.B. I943-I5-II502. The whole matter had been thrown into confusion by an earlier ruling, issued after the passage of the Rev. Act of 1942 and purporting to deal with 1942 and subsequent years, but apparently based solely on prior law. I.T. $3585,1942-2$, C.B. 158. This ruling had concluded that "Section $\mathbf{7 2 2}$ of the Internal Revenue Code is designed to afford relief in the case of certain situations not covered by other sections of the Code." 
ruling states that the statutory provision does not necessarily work in favor of the taxpayer in all cases:

Section $722(\mathrm{e}) 2$ of the Code, as amended, will also operate to deny the relief to an acquiring corporation entitled to such relief prior to a merger where the inclusion of the component corporation's business as its own will render the tax computed without the benefit of the general relief section fair and nondiscriminatory.

\section{Section 742(f)(I): The General Provision Against Duplication}

The foregoing discussion of the procedure for computing average base period net income under Supplement $A$ is subject to possible qualification in any case where, prior to the Supplement A transaction, the acquiring corporation has acquired stock of the component corporation by giving up assets rather than by issuing its own stock in exchange therefor. In such cases the Commissioner is given very broad authority to issue detailed regulations to prevent possible "duplication" of base period experience by reason of the fact that assets have left the corporate system.

The statutory provision, added by the $1942 \mathrm{Act}^{86}$ is brief and contains almost nothing in the way of standards or guides to limit the Commissioner's regulatory power thereunder. Indeed it is only by referring to the committee reports that one learns that the purpose of the section is to prevent "improper duplications of base period income and capital additions and reductions."87 The statute merely provides in substance that if, after December 3r, I935, the taxpayer has acquired stock in another corporation, and thereafter such other corporation becomes a component of the taxpayer-

then to the extent that the consideration for such acquisition was not the issuance of the taxpayer's . . . own stock, the Supplement A average base period net income of the taxpayer shall be reduced, and the transferred capital addition and reduction adjusted, in respect of the income and capital addition and reduction of the corporation whose stock was so acquired ... . in such amounts and in such manner as shall be determined in accordance with regulations prescribed by the Commissioner with the approval of the Secretary.

Such adjustments are also to be made-

... in respect of the income and capital addition and reduction of any other corporation which at the time of such acquisition was connected directly or indirectly through stock ownership with the corporation whose stock was so acquired and which thereafter became a component corporation of the taxpayer. ...

It should be noted that while Section $742(\mathrm{f})(\mathrm{r})$ comes into play only where stock is acquired for a consideration other than the issuance of stock in exchange therefor after December 3I, I935, the connection "directly or indirectly through stock owner-

\footnotetext{
${ }^{80} \$ 228$ (c). If the section had a functional forebear in prior law, it was old $\$ 742$ (e)( 1 ), dropped in the 1942 amendments. This section was a weak attempt at eliminating duplication, but was meaningless since it dealt with intercorporate dividends, which were not included in excess profits net income.

${ }^{87}$ House Report, p. 1550; Senate Report, p. 220; Conference Report, p. 35.
} 
ship" is subject to neither of these limitations as to time or manner of acquiring ownership. ${ }^{88}$

The remainder of Section $742(f)(I)$ consists of a qualifying sentence which states that stock shall be deemed to have been acquired in consideration of the issuance of the taxpayer's stock (and thus taken out of the scope of the section) where it has in the hands of the taxpayer a basis determined with reference to the basis of stock previously acquired by the issuance of the taxpayer's own stock. The general rules above stated, and this qualification, apply equally in the case of multiple Supplement A transactions, i.e., where one corporation has after December 3I, 1935, acquired stock in another corporation and thereafter both corporations become components of the taxpayer.

Analysis of the brief statutory language raises a host of questions, some of which are left without a satisfactory answer even by the detailed regulations. Before exploring the complexities, however, it may be well to look at the relatively simple basic theory underlying the section, as amplified by the regulations.

The basic theory of the regulations may be illustrated by the following example. Suppose, to keep the case simple, that corporations $A$ and $B$ are both in existence on January $\mathrm{r}$, r936, are on a calendar year basis, and are in no way connected by stock ownership. On December $3 \mathrm{r}$, 1937, $A$ purchases all the stock of $B$ from $B^{\prime}$ s stockholders for cash or other assets. The two corporations then continue in existence until at some later date, say on December 3r, r940, $B$ is liquidated or merged into $A$. In the absence of Section 742 (f) (I), $A$ would for I94x and subsequent years be entitled to compute its Supplement A average base period net income by adding together the separate earnings of $A$ and $B$ for each of the four years 1936-39. This result, however, would be open to the following criticism:

For the years 1936 and 1937 the combined average base period net income of $A$ and $B$ would represent the amount earned on assets in excess of those now held by $A$, the difference being caused and measured by the amount paid "out of the system" by $A$ to the stockholders of $B$ on December 31, 1937. If it may be assumed that the assets thus given up contributed to $A$ 's earnings in the years 1936 and 1937, then it seems only fair to make some corresponding downward adjustment in the combined earnings of $A$ and $B$ for 1936 and 1937 before allowing them to enter into $A^{\prime}$ 's Supplement $A$ income credit.

If a strictly logical course were followed, a detailed factual investigation might be made as to the extent, if any, to which the assets given up contributed to $A$ 's income in 1936 and 1937 , and the amount of such income would be eliminated from $A$ 's Supplement A average base period net income. This procedure, however, would in many cases involve such difficult and probably unanswerable questions as to make such a rule impossible to administer. The Commissioner has instead adopted a rule of thumb, which like all rules of thumb is doubtless intended to do rough justice

${ }^{88}$ This scems reasonably clear from the statutory language, and the regulations so state explicitly. See p. 93 , infra, note 94 . 
for the sake of administrative expediency. He starts with the assumptions, first, that the assets in question have contributed to $A^{\prime} s$ base period earnings and, second, that a fair approximation of the amount of such earnings may be found in the figure for $B$ 's earnings during the years prior to the stock acquisition by $A$. Although these assumptions are not explicitly stated in the statute, committee reports, or regulations, they appear to constitute the basic rationale of the regulations, and perhaps of the statute. ${ }^{89}$ On these assumptions the rule prescribed by the Commissioner is that, in the case stated above, the earnings of $B$ for the two years, r936 and I937, prior to the acquisition of $B$ 's stock by $A$, are to be eliminated.

Although in practice a $742(f)(I)$ transaction probably will not be as simple as the example given above, the basic method as prescribed by the regulations is the same in all cases. ${ }^{90}$ Reference should be made to the discussion and examples given therein ${ }^{91}$ in cases involving fiscal years and "vacant" years in the base period, acquisitions during a taxable year, acquisitions after the base period, ${ }^{92}$ partial and piecemeal acquisition of stock, several classes of stock of the component, capital additions and reductions, and multiple Supplement A transactions. .

Space prevents detailed analysis of these provisions but some idea of the pervasive operation of the section in the more complex situations may be gained from the examples involving multiple Supplement A transactions together with the "stock ownership" clause. ${ }^{93}$ These examples establish the following rules:

(I) If the taxpayer, $A$, acquires stock of a component, $B$, other than by the issuance of stock of $A$, not only is $B$ 's experience prior thereto excluded from $A^{\prime}$ 's Supplement A average base period net income, but so also is that of any corporation, $C$ (which later becomes a component of $A$ ), in which $B$ owns stock at the time and in the proportion in which $B$ holds such stock. ${ }^{94}$ Moreover, it is immaterial how or when $B$ acquired such stock, i.e., whether $B$ acquired such stock in a $742(f)(I)$ transaction.

${ }^{80}$ The committec reports speak of eliminating "experience attributable to stock acquired by the transfer of assets, which assets thereupon went out of the system" (CONFERENCE REPORT, 67), and "base period income and deficits for the base period years before the acquisition of such stock which is attributable to such stock. . .." SENATE Report, 221; House Report, 155.

${ }^{\circ 0}$ With one apparently erroneous exception. See note 92 , infra. Another inconsistent case originally contained in the regulations bas been changed. See note 93, infra.

${ }^{01}$ Section $742(f)(x)$ is treated generally in the regulations at $\$ 30.742-2(b)(3)$ (ii)(B). "Vacant years," however, are treated in $\$ 30.742-2$ (d), and capital changes in $\$ 30.743-2(\mathrm{~b})$.

${ }^{02}$ See regulations, examples involving corporations $J$ through $M$. The rule prescribed is to eliminate a portion of the experience of the year in question proportionate to the number of days of the year prior to the acquisition. This would seem erroneous where stock is acquired after the base period. See example ( 3 ) involving corporations $L$ and $M$. The proper result, in the light of the general approach of the regulations would seem to be to eliminate all $\mathrm{M}^{\prime}$ s base period experience in the year of acquisition as well as in later years.

${ }^{93}$ The examples referred to are those dealing with corporations numbered $R$ through $Z$ in the

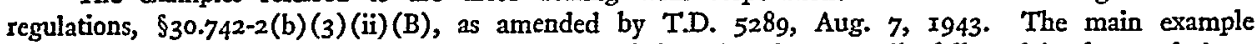
replaced by T.D. 5289 was erroneous, in the light of the principles generally followed in the regulations.

os This statement embodies the rules illustrated now by the two examples involving the $R, S$, $T$, and $U$ corporations. It is inconsistent with the former example ( $I$ ) involving the $R, S$, and $T$ corporations which appeared in the regulations prior to their amendment by T.D. 5289. See note 93 supra. 
(2) In addition, even where $A$ acquires stock of $B$ by the issuance of its own stock, if $B$ acquires the stock of $C$ in a $742(\mathrm{f})$ (I) transaction (and both $B$ and $C$ become components of $A$ ), $C^{\prime}$ 's experience prior to such acquisition by $B$ is excluded from $A^{\prime}$ 's Supplement $\mathrm{A}$ average base period net income. This is true even though $B$ 's acquisition of $C$ stock is later than $A^{\prime} s$ acquisition of $B$ stock. ${ }^{95}$

So much for the mechanics of $742(f)$ (I) as it has been interpreted by the Com. missioner's regulations. The important thing to note about the Commissioner's handiwork as a whole, however, is that it consists almost entirely of mechanics. Although the committee reports make it clear that the Congressional purpose is to eliminate duplication of base period experience, the Commissioner's exercise of regulatory power is not limited to cases where duplication is in fact found to result, ${ }^{00}$ nor even to cases where the absence of duplication cannot be clearly demonstrated. The regulations explicitly acknowledge the Congressional purpose, but they flatly state that the adjustments indicated by the examples given therein are to be made in all cases. The underlying principle of preventing duplication is not a limitation on these operative rules, but has the effect of extending such rules "to all other cases to which Section $742(\mathrm{f})(\mathrm{I})$ may be applicable, in a manner consistent with the principles underlying such described cases."97 "The regulations require a showing of actual duplication only in the limited type of case where $A$ acquires $B$ 's stock directly from $B$ rather than from $B^{\prime} s$ stockholders. In such a case no assets go out of the corporate system and therefore no duplication results. ${ }^{98}$

It is, however, perfectly possible for $A$ to acquire stock of $B$ from $B$ 's stockholders without giving up income-producing assets, and without resulting in duplication. For example, suppose $A$ buys stock of $B$ with cash it has just acquired by the issuance of stock, or indeed any idle cash which it has not been employing in its own business (and which does not result from the sale of assets the earnings of which were reflected in base period income). Or suppose $A$ acquires stock of $B$ by issuing long-term bonds. ${ }^{99}$ In such a case it is obvious that no assets have left the system, and that the same earning power remains in the combined corporate enterprise of $A$ and $B$ as before. ${ }^{100}$ Another case which is apparently subject to a

${ }^{20}$ See example dealing with corporations W, X, Y and $Z$, added by T.D. 5289 .

${ }^{\text {D0 }}$ See U. S. Treas. Reg., \$30:742(b)(3)(ii)(B), first paragraph.

${ }^{\text {or Ibid. }}$

${ }^{08}$ The case would be different of course, and the section might properly apply where $A$ acquires stock of $B$ which $B$ has just purchased from its own stockholders. In such case, the purchase would be from $B$ itself in form only.

"The examples given by the regulations refer uniformly to acquisitions for "cash," or "assets," rather than, in the words of the statute, acquisitions other than by the issuance of stock. However, it is doubtful that this variance can be relied upon. The regulations also refer to acquisitions by the taxpayer "for assets (other than its own stock)."

${ }^{100}$ It might be argued that the inequity of applying $\$ 742$ (f)(I) where stock is purchased for bonds is in some measure compensated for by the fact that the taxpayer gets the benefit of an interest deduction. This argument would lose force, however, where the purchase of stock for bonds takes place in the base period and the base period earnings are also thus reduced. Moreover, any benefit derived from adding an interest deduction after the base period might not be peculiar to Supplement $A$, but might simply represent an advantage possessed by any income credit taxpayer which, after the basc period, 
$742(\mathrm{f})(\mathrm{I})$ adjustment but which would not result in duplication is the situation where the consideration given by $A$ consists of stock of domestic corporations held by $A$ throughout the base period. The dividends on such stock, being excluded from excess profits net income, would not have added to $A$ 's earnings credit.

Another problem might be raised by contributions to capital. Suppose $A$, owning the stock of $B$ and $C$, contributes its holding of $C$ stock to $B$, and thereafter $C$ is merged into $B$. In such case the acquisition by $B$ is clearly by a means other than the issuance of its own stock; yet it is equally clear that no assets have left "the system" composed of $B$ and $C$. It is believed, however, that the improper result of a $742(f)(I)$ adjustment is prevented by the literal wording of the statute. The section calls for an adjustment "to the extent that the consideration was not the issuance of the taxpayer's . . . stock." In the case of contributions to capital there is of course no consideration given by the transferee corporation.

On the other hand, the literal wording of the statute would appear to permit the Commissioner to require an adjustment where stock of a component is acquired in exchange for treasury stock of the acquiring corporation, since the statute speaks of the "issuance" of stock of the latter. To the extent that the treasury stock was in turn acquired by the taxpayer by giving up assets an adjustment would, at least superficially, seem proper. But the automatic $742(\mathrm{f})(\mathrm{I})$ adjustment will not work out consistently with the basic method of the regulations where the treasury stock was bought in by the taxpayer well before the end of the base period and well before the subsequent exchange of treasury stock for stock of the component. Duplication would take place only with respect to the period up to the time of the acquisition by the taxpayer of its treasury stock, not the time of the subsequent exchange. However, the regulations do not touch on the problem at all. ${ }^{101}$

Many other cases of improper results and of unanswered questions, having tremendous dollars and cents consequences to corporations which happen to fall one side or the other of the arbitrary rules, will arise under the existing regulations. Some instances of occasional injustice are naturally to be expected wherever a rule of law takes the form of an arbitrary rule of thumb. In some fields of law

issues bonds and does not receive in return assets that earn more than the interest, or a taxpayer that recapitalizes after the base period by issuing bonds for its own outstanding stock. With respect to such a recapitalization, the statute does not seem to furnish clear evidence as to whether the benefit of the interest deduction would be offset by a capital reduction; and the answer may depend upon whether the recapitalization is a tax-free reorganization. Cf. $\$ 713(\mathrm{~g})(4)$; Le Tulle v. Scofield, 308 U. S. 415 (I940); Clarence J. Schoo, 47 B.T.A. 459 (1942) (Non-acq.), aff'd and dismissed, C.C.A. Ist, March 29, 1943; Edgar M. Docherty, 47 B.T.A. 462 (1942) (Non-acq.), remanded, C.C.A. Ist, Jan. 12, I943.

${ }_{101}$ A taxpayer in such a position would probably do well to argue under the existing regulations that only an adjustment for the shorter period is "consistent with the principles underlying . . . described cases." Cf. U. S. Treas. Reg., $\$ 30.742-2$ (b) (3)(ii)(B), first paragraph. However, resistance will probably be encountered from the Commissioner; for this catch-all provision appears to contemplate only "the adjustment under section $742(f)(I)$," which presumably is the indiscriminate elimination of all experience of a component prior to the acquisition of the component's stock. A recent case decided by the Tax Court would support the Commissioner's argument that there is no "issuance" where treasury stock is used. Firestone, 2 T. C. - No. 105, Sept. 20, 1943, C. C. H. Dec. No. 13,520 (involving Code, $\$$ Ir3 $\left._{3}(\mathrm{a})(7)\right)$. 
this is considered a fair price to pay for certainty. Familiar examples are to be found in statutes of limitations, statutes of frauds, zoning regulations, and the like. It is submitted, however, that in the highly delicate and complicated problems to which Section $742(\mathrm{f})(\mathrm{I})$ was directed, the regulatory straitjacket is impossible to justify on any grounds of certainty or administrative expediency. It was precisely because the problems were complex that rigid statutory rules were eschewed in favor of the supposed virtues of administrative flexibility. ${ }^{102}$ Unless the Commissioner adopts a different approach, therefore, it would seem that the only solution to the inequities that will inevitably result, and the only fair way of achieving the basic objective, is through further legislative action. Such action should ensure at the minimum that taxpayers will be given an opportunity to avoid the $742(\mathrm{f})(\mathrm{r})$ adjustment where they can show that duplication does not in fact exist.

\section{Section 740(c): Surviving Components and Related Problems Requiring the Elimination of Duplication}

Under the law prior to the 1942 Act, opportunities for duplication of earnings experience were not limited to cases where an acquiring corporation gained another's credit by giving up its own income-producing assets. Further opportunities arose from the fact that the draftsmen of the original act apparently lost sight of the component corporation once they got it up to the point of a Supplement A transaction. They seem to have focussed their attention exclusively on the main objective, that of giving to a corporation which acquires another's assets the past earnings experience that "belongs" with them, so to speak. No provision was made for taking this experience away from the component; and it was evidently overlooked that the component might continue in existence ${ }^{103}$ or, where the component was a substantially wholly-owned subsidiary, might transfer its income credit a second time when liquidated into its parent. ${ }^{104}$

The resulting possibilities for duplication in the use of a component's experience were, at least theoretically, quite remarkable. Let us suppose that $A$ acquired $B$ on December $3 \mathrm{I}, \mathrm{I} 93^{8}$ in a 740 (a)(I)(A) transaction, and that $B$, instead of liquidating, used the consideration received from $A$ to purchase new assets and continued in existence for the remainder of the base period. $A$ would quite properly get $B$ 's earnings experience prior to December 3 r, 1938. $B$ would, also quite properly, be given the earnings experience of its new assets for the period from December $3 \mathrm{r}, 193^{8}$ to the end of the base period.

However, $B$ would also still be allowed to use the experience attributable to its old assets prior to their transfer to $A$; and, if $B$ should subsequently become a com-

\footnotetext{
${ }^{102}$ See committee reports, note 87 , supra. In fairness to the Commissioner, it should be noted that the reports also furnish some basis for the use of the general type of automatic adjustment embodied in the regulations. See note 89 , supra.

${ }^{103}$ In cases under $\$ 740(\mathrm{a})(\mathrm{I})(\mathrm{A})$.

104 The liquidation (which is in fact required under $\$ \$ 740(\mathrm{a})(\mathrm{r})(\mathrm{B})$ and (C)) itself qualifies as a Supplement A transaction under $\$ 740$ (a)(2).
} 
ponent of another corporation, $C$, the latter would inherit this same base period experience. In addition, $A$ would literally be allowed to use the earnings experience of $B$ after December $3^{\text {r, }}$ 1938, which was attributable to the new assets never at any time possessed by $A$. The incongruous results might multiply as complexities and variations enter the picture. For example, either $A$ or $B$ might have further Supplement A transactions of the same sort; and any of the transactions might occur either during the base period or thereafter.

The obviously unsound results just indicated have been cured by the new Section 740 (c), added by the 1942 Act. ${ }^{105}$ Although the new section is cloaked in language as forbidding and involved as any that can be found in the law, its effect can be expressed in a simple basic principle, namely that earnings experience shall follow from corporation to corporation the group of assets to which it is attributable. This principle has been embodied in three main rules which, leaving aside qualifications and exceptions, provide as follows:

(I) If $B$ becomes a component of $A, B$ may not thereafter use its earnings experience prior to the day of the transaction. ${ }^{106}$

(2) However, in computing $B^{\prime} s$ tax for its taxable year during which the transaction occurred, $B$ may use a portion of its earnings experience, pro-rated according to the number of days in its taxable year prior to the transaction. ${ }^{107}$

(3) $A$ does not get the benefit of any of $B$ 's earnings experience subsequent to the transaction. ${ }^{108}$

The first two rules, limiting the credit available to the component, apply by their terms only to taxable years beginning after December 3 , I94r. The third rule, limiting the credit of the acquiring corporation, applies to all taxable years beginning after December $3 x$, I939. ${ }^{109}$ Thus none of the provisions of the new section are subject to the general election as to retroactivity of the 1942 amendments.

Looking more closely to the details of the statutory language, we note that the basic rule for limiting the credit of the component-rule (I) above-applies equally to any other corporation ${ }^{110}$ which either immediately ${ }^{111}$ or at some later time ${ }^{105} \$ 228(\mathrm{a})$. The former $\$ 740(\mathrm{c})$, defining a "qualified component corporation," was eliminated.

${ }^{100}$ INT. REv. CoDE $\$ 740(\mathrm{c})(x)$. This section is subject to qualification by the rule of $\$ 740(c)(2)$, immediately following.

${ }^{107} \mathrm{Id}$. $\$ 74^{\circ}$ (c) (2). This rule may apply whether or not the component is immediately liquidated. See note III, infra. Although $B$ thus is permitted a portion of its earnings experience, it does not take account of any of its capital addition or reduction attributable to the time immediately before the transaction. SENATE RePORT, 2I7; House Report, 152.

${ }^{108}$ INT. REv. CODE $\$ 740$ (c), last sentence. This rule by its nature can apply only where the transaction occurs during the base period and the component continues in existence.

${ }_{100}$ Rev. Act of $1942, \$ 228(\mathrm{f})$.

110 The language of the statute is "an acquiring corporation of which the acquiring corporation in such transaction is not a component." This makes clear that although the second acquiring corporation ordinarily is excluded from using the experience of the component, this would not be true where the second acquiring corporation acquires, or has acquired, the first acquiring corporation.

${ }^{112}$ Section $740(c)$ is not limited to cases of surviving components, but may include exchanges which are required by $\$ 740$ (a) to be followed by liquidation of the transferor. See SENATE REPORT, 2I5; House REPORT, 15I. Thus the transfer by a wholly-owned subsidiary of all its assets to a corporation 
acquires the component in a Supplement $A$ exchange. Moreover, if $B$ itself had components prior to its transaction with $A, B$ loses their experience as well as its own. This result is of course consistent with the basic principle of the section, since such experience is all given to $A^{112}$

The basic rule of Section 740 (c) (r) does not apply where the growth formula is used, except for purposes of limiting the average base period net income by the net income of the best base period year. Thus, while the component in effect gets a substitute $^{113}$ for the earnings experience given to the acquiring corporation, the latter exception means that the component's income credit is limited by its best year subsequent to the Supplement A exchange.

With respect to the operation of rule (2), applying to the computation of the tax for the year of the Supplement A exchange, it is to be noted that the rulewhen taken together with Section $742(f)(2)$, the analogous provision for acquiring corporations-does not simply slice a single credit into two parts. Such a result is achieved only where the taxable year of both corporations covers the same period and where both corporations continue in existence throughout such year. The component's earnings experience in other cases may in a sense do double duty, though without improper duplication. This follows from the fact that both corporations receive a portion of the experience, according to the number of days in their respective taxable years which is determined separately for each corporation before and after the transaction, respectively.

Thus for example suppose the component, $B$, continues in existence, after a Supplement A exchange transferring its assets to $A$ on June 30 , r943, and that $A^{\prime} s$ taxable year begins June ist and $B^{\prime} s$ March Ist. For its taxable year from March I, I943 to March I, 1944, $B$ would be allowed to use roughly $1 / 3$ of its base period experience. $A$, on the other hand, would be allowed in its taxable year from June I, I943 to June I, I944 to use roughly Ir/I2 of $B^{\prime} s$ experience. These results are of course proper since in each case they represent the portion of the respective taxable years during which the assets are held.

In cases where the component goes out of existence immediately after the Supplement A transaction, it is not deprived of any of its base period income in computing its tax for the year of the transaction. Thus if $B$, on a calendar year basis transferred all its properties to $A$ on June 30,1943 and was forthwith liquidated, its taxable year 1943 would be from January ist to June 30 th. The number of days in the taxable year prior to the transaction (I8I) would be the same as the total

other than the parent, in exchange for voting stock, followed by a liquidation of the subsidiary by the parent, would not transfer the income experience of the subsidiary to the parent. Such experience would belong exclusively to the transferee of the assets. Similarly, a corporation completely liquidated but not dissolved would not, if revived by new capital, retain the base period income passed on to an acquiring corporation immediately prior to the liquidation.

${ }^{113}$ INT. REV. CODE $\$ \$ 740(\mathrm{~g}), 742(\mathrm{a})$.

${ }^{213}$ With this possible exception, no provision is made for giving the component a substitute to fill in the portion of its base period the earnings experience of which is exclusively given to the acquiring corporation. See p. 99, infra. 
number of days in the taxable year; and therefore the application of the prescribed ratio would give $B$ r00\% of its base period net income. $A$, if also on a calendar year. basis, would nevertheless be allowed, under Section $742(f)(2)$, to use approximately one-half of $B$ 's base period income in computing its tax for 1943 under Supplement $\mathrm{A}$. The results are again perfectly proper since $A$ will have the income from the assets for half the year, and $B$ is required to annualize its excess profits net income in computing its tax. ${ }^{114}$

The new provisions of Section 740 (c) can as a whole fairly be said to have achieved their objective of ensuring that earnings experience follows assets. But while the section thus deprives a surviving component or its successors of past base period experience attributable to the transferred assets, it stops there and makes no provision for a substitute, except by the use of the normal growth formula. ${ }^{115}$ No automatic "fill-in" with constructed income based on invested capital is available, since such fill-ins are granted only for periods during which a taxpayer is "not in existence."110

It would seem that the Commissioner might rectify this casus omissus in the statute through the general relief provisions of Section 722. In such event, the measure of the constructive income would properly seem to be not less than the earnings of the assets newly acquired by the surviving components during the period, if any, when they were operated by the former owner. But the assets may of course have no history of former operation; and, in any event, the applicant for relief under Section 722 cannot feel secure in the belief that it will automatically ${ }^{117}$ get the full measure of replacement of its earnings credit to which it would be entitled if provision had been made in the statute, allowing, for example, the use of fill-ins under Sections $7 \mathrm{r}_{3}(\mathrm{~d})(2)$ or 742 (e). Save for the possible benefits of Section 722 , the surviving component appears under the present provisions of law to have only the alternatives of the invested capital credit or an amputated income credit.

\section{Conclusion}

The foregoing discussion describes in some detail the operation of the provisions controlling the excess profits credit consequences of corporate readjustments. A brief but more general word should be said as to the adequacy of these provisions. The difficulty of ascertaining the rule of the statute and translating it into dollars of credit, is by no means the most serious complaint which taxpayers (and Bureau examiners) are entitled to register. That problem (when tied in with the rest of the excess profits tax structure) requires, more or less, infinite patience with the obstacles created by sheer intricacy of expression; a student's enjoyment of the sub-

${ }^{124}$ INT. Rev. Cone $\$ 7 \mathrm{II}(\mathrm{a})(3)$. The result as to $B$ is explicitly recognized by the regulations. U. S. Treas. Reg. $109, \$ 30.740-2$ (c) (3).

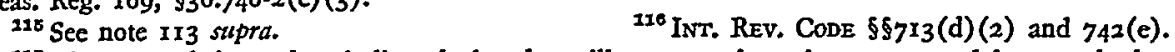

117 The Commissioner has indicated that he will not acquiesce in any 722 claim merely because grounds for relief and the proper measure of reconstruction are clearly demonstrated. He feels free to make wide use of what might be termed equitable offsets, such as for example "above normal earnings" in other years. See U. S. Treas. Reg. 109, $\$ 722-2(b)(2)$; and of. I.T. $3^{617}$, quoted at p. 91, supra. 
ject; an expert application of the technique of statutory construction; a knowledge of the painful growth of our tax legislation through its twenty-odd statutory revisions; a grasp of hundreds of legal principles decided, half-decided, twisted or ignored in the thousands of tax decisions handed down by too many courts of law having tax jurisdiction; familiarity with thirty years of income tax administration by the Bureau; the development, step by step, of the business since its inception, including the financial history of its predecessors-although this will often be tantamount to a review of half a century of business activity; the tax biography of the business for the same period; a corps of fact-finding and mathematical personnel; a seer of the future success of the enterprise; and many things more elusive which might seem even less credible on paper. On top of this, it may be necessary to thread the maze of the consolidated returns regulations!

There are, however, curious people who will devote their time and abilities to problems of this sort; and the common wilderness into which both government and taxpayer investigations and analyses ultimately trail off draws a practical line on the theoretical reaches of the problems. Consequently, a solution--some solution-is reached. When the final computation is made, however, the taxpayer may frequently well question what the figure arrived at has to do with an amount reflecting the "fair," "normal," or "non-excessive" earning power of the enterprise. The 
Little knowledge of our "reorganization" tax law is required to realize that it is often largely fortuitous whether a "reorganization" occurs, and that more or less minor variations in several plans of reorganization (the differences having sound business or practical justifications, but no conceivable relationship to rational taxing policy) may therefore produce widely different excess profits tax results. The recent Southwest Consolidated and Alabama Asphaltic cases ${ }^{118}$ reveal the capricious grounds on which income tax distinctions are made in determining whether or not a "reorganization" occurs. These opinions indicate that an incidental factor, such as the issuance of a few stock warrants, or the assumption of a liability which arose in the course of reorganization, may be sufficient to disqualify the transaction under the reorganization provisions-although it may be the truest kind of business reorganization.

The inadequacy and unrealistic operation of the "reorganization" provisions of Sections II2 and II3 are well known; and their functioning is open to common and justifiable criticism even when limited to the narrow problem of determining only when taxable gain or loss is realized. It is much more difficult to justify increasing the burden of such legislation to the point of controlling a substantive matter of such importance as the excess profits credit.

Even assuming the desirability of tying in with the income tax provisions, the excess profits tax provisions controlling corporate readjustments may be further criticized for not having been worked out in a harmonious and consistent pattern. In this connection a good example is the treatment of deficits for invested capital purposes which is more specifically discussed above. The general provisions of Section $7^{18}$ are supposed to embody the basic policy of the "deficit rule," that is, a deficit in earnings does not reduce invested capital. However, Section 760 has been so constructed as to "squeeze out" the deficit if a corporate readjustment occurs. On the other hand, the rules of Section 718 with respect to "identity" reorganizations seek, in a half-hearted way, to counteract this effect by restoring the deficit. As a final twist, the provisions of Section $76 \mathrm{r}$, which involve precisely the same deficit problem on corporate readjustments by way of inter-company liquidations, merely ignore the problem.

Another weakness in the statutory structure-despite the fact that it reflects an effort to prescribe a detailed and complete, even though highly theoretical and technical, pattern for determining the effects of a corporate readjustment-is that it nevertheless provides no rule at all (other than the implication of the general rule) for large segments of the problem. Consider, for example, the effect on invested capital of a reorganization within the framework of the existing corporation by way of recapitalization. No mention is made in the various excess profits tax provisions of the treatment of reorganizations of this common sort. The matter is particularly acute in the reorganization of financially distressed corporations through the procedures of the Chandler Act. Indeed, there is a large gap in the income tax

\footnotetext{
${ }^{118}$ Supra note 8.
} 
law with respect to reorganizations of this particular type. If debt structures are drastically reduced or eliminated, and the equity in the company (for what it may be worth) is turned over to the bondholders and other creditors in the form of no par common stock by way of recapitalization, what is the effect on invested capital? Has the old equity capital, previously represented by the old stock wiped out in the reorganization, disappeared for tax purposes? As a matter of technical construction, it would appear not. Is the entire amount of the debt structure now to be regarded as converted into equity capital because the interests of the erstwhile bondholders are now represented by stock-despite the fact that the capital structure for business and book purposes is radically altered from its character prior to the recapitalization? This would seem the most probable result under present law. Should not the investment in the assets surviving reorganization be in some way considered? This is probably what the law should provide as a minimum. These are questions that it is impossible to answer by reference to the tax statutes for no attempt has been made to deal with them.

On the income credit side, other (though perhaps less important) gaps have been left in the statute, which have been specifically mentioned. In addition, the solution of duplication problems under Section 742 (f) (I) by legislative abdication to administrative authority, without limitation or guide of any ascertainable scope, is no less a failure to meet an important problem.

Finally, a very close examination of any of the provisions relating to corporate readjustments clearly reveals that their detailed approach is illusory and deceptive. Although they at first appear to have deliberately covered by specific provision virtually all the problems involved, it soon develops that they in fact have created or failed to consider many more problems than would appear on the surface. Numerous examples of this type of weakness have already been stated.

The solution? Perhaps there is none. Knowing the high technical ability and conscientious bent of both the policy-makers and draftsmen who have produced the excess profits tax law, it is not easy to say that a better product ought to have been forthcoming. The only answer, it seems, lies in maintaining a continous process of ferreting out specific weaknesses, and willingly recognizing and acting upon the necessity for suitable remedies. 